\title{
GITANOS, MOROS Y NEGROS ANTE LOS TRIBUNALES: COLONIALISMO Y RACISMO INSTITUCIONAL DURANTE LA SEGUNDA REPÚBLICA ESPAÑOLA (1931-1936)*
}

\section{GIPSIES, MOORS AND NEGROES BEFORE THE COURTS: INSTITUTIONAL COLONIALISM AND RACISM DURING THE SPANISH SECOND REPUBLIC (1931-1936)}

\author{
Rubén Pérez Trujillano \\ Universidad Internacional de La Rioja
}

\begin{abstract}
SUMARIO: I. INTRODUCCIÓN.- II. GITANOS.- 2.1. Racismo inducido por el discurso judicial.- 2.2. Racismo deducido del discurso judicial.- 2.3. Gitanidad, nación y República.- III. MOROS.- 3.1. Jurisdicción militar.- 3.2. Jurisdicciones indigenas.- 3.3. Africanismo, justicia y Constitución.- IV. NEGROS.- 4.1. Cambio de régimen y permanencia de Estado.- 4.2. Jurisdicción teórica y jurisdicción real.- 4.3. Lógica colonial y justicia para blancos.- 4.4. Lógica colonial y justicia para negros.- V. CONCLUSIÓN.
\end{abstract}

Resumen: Este artículo analiza de qué manera la relación entre constitucionalismo y colonialismo generó problemas al proyecto de construcción de ciudadanía y de garantía de derechos durante la Segunda República española. Se estudia la normativa, pero también diversos archivos judiciales y administrativos con el objetivo de desenmarañar cuál fue la interpretación del derecho $y$ el funcionamiento cotidiano de las distintas instancias que participaban en la administración de justicia (jueces, fiscales, policias y militares). Al final, se sostiene que el comportamiento de la administración frente a estas realidades constituye uno de los reflejos de la existencia de una resistencia institucional al Estado constitucional, sin ignorar el lado oscuro que el mismo tenía.

\begin{abstract}
This article analyses how relations between constitutionalism and colonialism caused problems to the citizenship-making project and the guarantee of rights during the Spanish Second Republic. Regulations are studied, but also various judicial and administrative archives with the aim of unravelling the interpretation of law and the day-to-day running of the bodies involved in the administration of justice (judges, prosecutors, police and military). In the end, it is argued that the behaviour of the administration in the face of these realities constitutes one of the reflections of the existence of institutional resistance to the Constitutional State, without ignoring its dark side.
\end{abstract}

\footnotetext{
* Este texto es el resultado de una investigación desarrollada en el marco del V Plan Propio de Investigación de la Universidad de Sevilla. La última fase de elaboración se benefició de una estancia posdoctoral como visiting fellow en el Sheffield Centre for International and European Law, así como de los debates alli sostenidos, entre otros, con el profesor Pablo Castillo-Ortiz. También debo dar las gracias al Departament de Dret de la Universitat Pompeu Fabra, en donde fui acogido como investigador visitante predoctoral en un período decisivo, y en especial al profesor Alfons Aragoneses.
} 
Palabras clave: Segunda República española, Europa de entreguerras, Estado constitucional, poder judicial, colonialismo, racismo.

Key Words: Spanish Second Republic, Interwar Europe, Constitutional State, Judicial Power, colonialism, racism.

\section{INTRODUCCIÓN}

La Segunda República trajo a España las primicias del Estado constitucional. La revolución del 14 de abril de 1931 y la Constitución promulgada a finales de dicho año proclamaron derechos fundamentales $y$ erigieron poderes subordinados a la soberanía popular. Mientras que los primeros contaron con garantías politicas y jurisdiccionales, los segundos incorporaron limites, ya fueran políticos -como el principio democrático- o jurisdiccionales como el control de constitucionalidad ${ }^{1}$. No obstante, el constitucionalismo republicano $\mathrm{y}$, en general, el constitucionalismo de entreguerras, poseía un reverso oscuro que afectaba a la población originaria de los territorios coloniales y a ciertos sectores de la población localizada en la metrópoli. En otras palabras, la cara oculta del constitucionalismo no sólo era la que excluía a una humanidad del estatus de ciudadanía o incluso de la titularidad de derechos fundamentales, sino que -como resultado de su racialización- marginalizaba y discriminaba a algunos grupos humanos formalmente incluidos por el sistema constitucional.

El estudio de esta cuestión es de crucial interés para la comprensión de la historia del Estado constitucional español. Sin embargo, se trata de un tema generalmente ausente, incluso, en la historiografia más autorizada ${ }^{2}$. En este artículo se pondrá el foco sobre los órganos encargados de administrar justicia. La justicia entraña un cuerpo burocrático dotado de singular autonomía respecto al conjunto de la administración, como destacaron algunos contemporáneos agudos $^{3}$. Por tanto, el estudio de su funcionamiento contribuirá a la detección de dos líneas de tensión en el proceso de implantación del constitucionalismo durante el período 1931-1936. La exploración de la carga discriminatoria existente por motivos étnicos o raciales en la práctica judicial permite vislumbrar, de un lado, las limitaciones intrínsecas al modelo constitucional fundado en 1931. Pero también, de otro, las limitaciones extrínsecas al mismo, esto es, aquellas derivadas de la peculiar actuación autónoma de las autoridades judiciales, fiscales, policiales y militares ${ }^{4}$.

1 Sebastián Martín, "Derechos y libertades en el constitucionalismo de la II República", en Ana Martínez Rus y Raquel Sánchez García (coords.), Las dos repúblicas en España, Editorial Pablo Iglesias, Madrid, 2018, pp. 43-78.

${ }^{2} \mathrm{La}$ que merecidamente constituye la obra de referencia sobre el período republicano sólo dedica alguna mención fugaz al hecho colonial. Eduardo González Calleja, Francisco Cobo Romero, Ana Martínez Rus y Francisco Sánchez Pérez, La Segunda República española, Pasado \& Presente, Madrid, 2015, p. 268.

3 Por todos: Harold J. Laski, El Estado en la teoria y en la práctica, Revista de Derecho Privado, Madrid, 1936, traducción de Vicente Herrero, pp. 153 y 204.

4 Este artículo pivota sobre diversas fuentes de archivo. Vayan por delante su enumeración y las siglas correspondientes a cada cual: Archivo de la Audiencia provincial de Sevilla (AAPS), Archivo de la Biblioteca Nacional de España (ABNE), Archivo del Congreso de los Diputados (ACD), Archivo del Consejo de Estado (ACE), Arxiu Central del Tribunal Superior de Justicia de Catalunya (ACTSJC), Archivo General de la Administración (AGA), Archivo General Histórico de 
El naufragio de la República en su objetivo de generalizar los derechos de ciudadanía dentro de la comunidad politica siguiendo el principio de soberanía popular tuvo impronta judicial y conoció, al menos, las siguientes gradaciones: "gitanos", "moros" y "negros". Como veremos en las siguientes páginas, a cada comunidad, definida -que no inventada- por las instancias judiciales, se le asignó un estatus procesal desventajado con mayor o menor intensidad y más o menos coherente con las propias limitaciones del ideal republicano. Los "gitanos" representaban el otro interior para el pueblo soberano. Los "moros" y los "negros", el otro exterior. En un plano diferente, el utillaje conceptual del colonialismo realizó viajes de ida y de vuelta entre África y Europa. En atención al eje de la africanidad, consistente en la importación desde territorio africano de conductas e imaginarios colonialistas hacia el interior de la Peninsula Ibérica y las islas asimiladas, puede decirse que si el discurso judicial racista sobre los "negros" aludia al África occidental, el discurso referente al África septentrional incorporaba a los "moros". El caso de los "gitanos" dibujaba una especie de África peninsular.

\section{GITANOS}

Pese a los grandes enunciados del constitucionalismo hegemónico y su envoltura abstracta -que alimentaba el individualismo engañoso según el cual realidades y sujetos múltiples quedaban abarcados sin distinción-, y por encima de la igualdad ante la ley y las libertades preconizadas por los códigos (arts. 4 y 10 de la Constitución de 1876), las lógicas aplicativas mostraban un perfil muy distinto del derecho español cuando cayó la monarquía. En ocasiones, esas lógicas se vislumbraban no ya en las prácticas de la autoridad -judicial o nosino que, además, eran objeto de enunciación explícita. De derecho observado pasaban a derecho leído; de derecho deducido a derecho inducido; de ley supuesta a ley verdaderamente formulada.

Tal es el caso del reglamento para la administración y régimen de las reses mostrencas, aprobado en 1905. Decía el art. 2:

Las reses cogidas por la Guardia civil o las Autoridades, en cumplimiento de la Real orden de 8 de septiembre de 1818, a los gitanos y traficantes de ganado en las ferias y mercados, sin documento que acredite la legítima posesión y sin que sea conocido su verdadero dueño, se considerarán mostrencas y se regirán por este reglamento. ${ }^{5}$

A través de esta norma de rango inferior a ley $\mathrm{y}$, por supuesto, a Constitución, el Ministerio de Agricultura, Industria y Comercio injertó en el

\footnotetext{
Defensa (AGHD), Archivo Histórico Nacional (AHN), Archivo Histórico Provincial de Badajoz (AHPB), Archivo Histórico Provincial de Cádiz (AHPCad), Archivo Histórico Provincial de Córdoba (AHPCo), Archivo Histórico Provincial de Sevilla (AHPS), Archivo Histórico del Tribunal Militar Territorial Segundo (AHTMTS), Arxiu Nacional de Catalunya (ANC), Archivo de la Real Academia de la Historia (ARAH), Archivo de la Real Chancillería de Granada (ARCG) y, por último, varios archivos de la Fundación Anselmo Lorenzo (FAL) y de la Fundación Pablo Iglesias (FPI). También uso abreviaturas útiles para carpeta (carp.), expediente (exp.), Gaceta de Madrid (GM), legajo (leg.), sig. (sig.) y tomo (t.), además de las más usuales.
}

5 Real decreto de 24 de abril de 1905 aprobatorio del adjunto reglamento para la administración y régimen de las reses mostrencas, GM, nº 115, 25 de abril de 1905, pp. 339-340. 
ordenamiento jurídico del Estado español el principio de presunción de culpabilidad de esa parte de la humanidad que se conoce -inicialmente en el lenguaje del poder- como los gitanos y gitanas.

De entrada, el principio admitía prueba en contrario -el documento acreditativo de la posesión-, pero no cuesta imaginar que en la vida cotidiana aquella operase como una presunción iuris et de iure, ya que los negocios de transmisión posesoria de reses solian ser verbales y por lo usual no dejaban rastro documental, como demuestra el hecho de que la doctrina categorizase la figura del adquiriente de buena fe sin otorgar un valor esencial a la tenencia de documentación ${ }^{6}$. La propiedad se acreditaba más vivamente mediante muescas o marcas en el ganado ${ }^{7}$, cuando no mediante el testimonio de $\operatorname{terceros}^{8} \mathrm{y}$, cuando fuera posible, de la otra parte contratante $^{9}$. Muchos sumarios se instruyeron durante 1931-1936 por la sospecha policial de que cierto semoviente había sido robado porque su poseedor actual carecía de documentación acreditativa de su legitima procedencia, pero por lo general terminaban siendo archivados después de algunas tomas de declaración que despejaban las incógnitas acerca de la legitima posesión creadas por la falta de prueba documental ${ }^{10}$. Además de estas situaciones controvertidas, no hay que olvidar la imposibilidad práctica de poseer justos títulos de los animales cuando éstos eran criados desde su nacimiento. Muchas de estas sospechas pivotaban sobre prejuicios anti-gitanos y nada más, como iremos desgranando.

El precepto reglamentario no se hallaba circunscrito a relaciones mercantiles para el caso de los gitanos -tal era el condicionante obvio de los traficantes de ganado-, sino que tenía un alcance general para todos los miembros de ese grupo particular constituido por la etnia romaní. El derecho de propiedad privada presunto, atribuido a hipotéticos propietarios legítimos de los animales sustraídos -propietarios gachés-, se convertía en todo un poder de expropiación sin garantías de indemnización ni de ningún tipo. Bartolomé Clavero, de quien recibí la pista sobre esta norma, ha considerado que así

${ }^{6}$ Extraeré algunos de los múltiples ejemplos que pueden hallarse en el último año republicano: sentencias de la Audiencia provincial de Sevilla $n^{\circ} .37$ (21-I-1936), n ${ }^{\circ} .86$ (12-II-1936) y n .135 (3-IV-1936). AHPS, Libro de sentencias de 1936, Título 1-163, t. I, sig. L-3204.

7 Se explicarian así tres factores constantes en las causas criminales estudiadas: 1) el ínfimo número de procesamientos de compradores de caballerias robadas, 2) la tendencia absolutoria en los pocos que se producían y, por último, 3) la falta de presentación de documentación que probase la propiedad por parte de quienes denunciaban que se le había sustraído algún semoviente. Según leemos en la sentencia n ${ }^{\circ}$. 104 (10-V-1933) dictada por la sección $2^{a}$ de la Audiencia de Sevilla, el procesado habia adquirido una mula hurtada a un desconocido en la feria de Cártama "sin exigirle documento alguno que acreditase la posesión y debiendo sospechar de ella al ver que no la tenían”. Así lo estimaba el fiscal en su escrito provisional, que pedia que se le condenase por encubrir el delito de hurto. Sin embargo, terminó retirando la acusación, dándose fin al proceso. AHPS, Libro de sentencias de 1933, Título 1-345, sig. L-3110.

8 En muchas denuncias por la desaparición de caballerias los propietarios tan sólo podían aportar el testimonio de algunos vecinos como prueba de su título legítimo y de "la preexistencia" de los ejemplares. AHPS, caja 3162, sumario $\mathrm{n}^{\circ} .209 / 1932$, pp. 1-1 vº, 5 y 8-9.

9 Véanse dos causas seguidas por el Juzgado de instrucción de Rute (Córdoba) por "intervención de una caballería de ilegítima procedencia": AHPCo, caja 6600, sumarios $\mathrm{n}^{\circ}$. $32 / 1931 \mathrm{y} \mathrm{n}^{\circ} .39 / 1931$. Este último evidencia con más claridad el prejuicio anti-romaní en el mismo lenguaje judicial, y que sólo se disiparía con la declaración de un tratante de ganado favorable a la legitimidad del negocio (pp. 18-19 y 42).

10 Los declarantes solian ser inspectores veterinarios de compañias de seguros, supuestas víctimas de robo de caballeria, etc. AHPS, caja 5586 (3/3), sumario ${ }^{\circ} .46 / 1934$, pp. 1 y 4. 
quedaba sentada "la regla de que los gitanos no son dueños, sino ladrones"11. E1 para-derecho, integrado por una maraña de disposiciones normativas incardinadas en los últimos peldaños de la jerarquía normativa, podía ser tan importante como la cúspide de la misma, lo que quiere decir que los sistemas de fuentes del derecho y el principio de legalidad tenian una vigencia más que cuestionable en el ordenamiento jurídico liberal y que la Constitución total de España resultaba de un enjambre de disposiciones y actos normativos de desigual hechura. Es lo que Daniel J. García y Pablo Castillo han descrito, en su estudio sobre la represión de los gitanos bajo el franquismo, como un "tabú" formado de "microcapilares jurídicos"12.

El trazado judicial del racismo anti-romaní presenta una sorprendente continuidad que enlaza el sistema de la Restauración, la dictadura de Primo de Rivera, la República y la dictadura de Franco; es decir, regimenes liberales, autoritarios, democráticos y totalitarios. En 1926 la Audiencia provincial de León juzgó a un comisario jefe de vigilancia al que se acusaba de varias exacciones ilegales y estafas. Una de ellas, recogida por el escrito de conclusiones provisionales del Ministerio fiscal, aseguraba lo siguiente:

el referido Comisario interino, en las diligencias practicadas por hurto de mantón a la vecina de León, Agustina González Benavides, y como se sospechara que los autores habian sido gitanos, llamó a la Comisaría a Francisco García [gitano, se entiende], al que dijo que o aparecía el mantón o entregaban 50 pesetas, en las que la dueña calculaba su valor, o detendría a muchos gitanos...

Francisco García hizo lo que se le exigía. Este supuesto ilustra lo que vengo explicando sobre el principio de presunción de culpabilidad de la población romaní -que queda explícito en la norma citada, pero no tanto en la aplicación judicial anteriormente expuesta, cuyo sentido puede así desvelarse- y, no ya su vigencia entre las fuerzas de orden público o su admisión por las autoridades judiciales, sino la conciencia de discriminación vivida por los propios gitanos. García pagó, sin ser culpable él ni posiblemente ningún gitano, porque sabía que el comisario, si se lo proponía, podía de veras detener "a muchos gitanos". Pero el hecho no suscitó una exigencia de responsabilidad penal al comisario por el abuso de autoridad o la extorsión. Esa conducta quedó impune a ojos de todas las partes procesales. Lo que importaba era la estafa sufrida por la damnificada, ya que:

el Francisco entregó a dicho Comisario, hoy procesado, las 50 pesetas hoy reclamadas, de las que sólo entregó 35 a la Agustina, diciéndole que sólo eso habia entregado el Francisco, aprovechándose asi en 15 pesetas, en que defraudó a la dueña, sin que diera cuenta al Juzgado correspondiente del hurto relacionado.

11 Bartolomé Clavero, "Legislación universal para pueblos modernos (1868-1914): un programa de textos para una comunidad de naciones", en Víctor Tau Anzoátegui (ed.), La revista juridica en la cultura contemporánea, Fundación Centro de Estudios Políticos y Administrativos-Ediciones Ciudad Argentina, Buenos Aires, 1997, pp. 31-55, cita en p. 52.

12 Daniel J. García López y Pablo Castillo Ortiz, "La represión silenciosa del pueblo olvidado: gitanos bajo el franquismo", en Federico Fernández-Crehuet López y Daniel J. García López (coords.), Derecho, memoria histórica y dictaduras, Comares, Granada, 2009, pp. 367-396. 
A nadie se le ocurrió cuestionar tan flagrante discriminación racista. Tampoco al Tribunal Supremo. Cuando dos años después falló sobre el asunto, la pasó por alto y legitimó, por consiguiente, semejante grado de institucionalización del racismo y su recepción e impulso jurisprudencial de principio a fin ${ }^{13}$.

Esta realidad represiva fue arrastrada por la República. La lectura conservadora de la ley de vagos y maleantes (LVM), en el segundo bienio, manifestaría la deuda con la regulación anti-romaní que acaba de mencionarse ${ }^{14}$. Ahora bien, la actitud racista impregnaba la aplicación de todo el derecho penal y por extensión, posiblemente, de todo el derecho. Centrándonos en el campo de la interpretación, la mera sospecha de un comprador acerca de la "mala procedencia" de un animal adquirido a bajo precio justificaba la actuación de la Guardia civil a través de interrogatorios, decomisos, etc. El trastorno ocasionado a la comunidad gitana era notorio. Entre tanto se sustanciaba la causa, la caballería -un medio de tracción, de transporte, de trabajo e incluso de vida- era incautada por la Guardia civil. No sólo eso: también solía acompañar la detención del vendedor y su traslado a la prisión provincial, incluso, "en concepto de detenido (...) por el delito que se ignora". Tal era la fuerza de la presunción de culpabilidad que la diligencia de arresto personal tenía un carácter puramente protocolario. Después entrarían a actuar otro tipo de autoridades públicas (alcaldias, registros civiles...) y policiales (policía gubernativa, guardia municipal...), en función de las órdenes dadas por el juzgado de instrucción para la confección y recopilación de información sobre el sujeto. En ningún sumario del período 1931-1936 se ha encontrado alusión al reglamento de 1905, por lo que cabe barajar dos hipótesis: que a esas alturas del siglo XX compusiera más bien una muestra literaria de una práctica real ajena a textualidad alguna, antes que una habilitación jurídica expresa; o por el contrario, que lo dispuesto en el reglamento citado y a saber en qué otras órdenes más se había transformado en una verdadera práctica asentada en las fuerzas de orden público y en las autoridades, más cercana al derecho consuetudinario que al escrito. Nada alteró esta circunstancia la entrada en vigor de una Constitución normativa en 1931.

Cualquiera que sea la premisa, lo que sí que se ha constatado es que el funcionamiento de la discriminación por razón de etnia gitana era más omnivoro. Operaba una discriminación por razones étnicas en sentido amplio, cuya comprensión absoluta resulta difícil a la vista de la documentación conservada, ya que la opresión racista no siempre empleaba un léxico racista. Por ello, un buen método de aproximación al material de archivo puede ser aquel que atienda a los rastros judiciales de un trato discriminatorio inducido (1) o inferido del uso del lenguaje, así como los ponga en relación con las categorías producidas por las fuerzas de orden público (2). Aunque de manera menor y casi imperceptible, se

13 Sentencia del Tribunal Supremo (STS) de 13-XII-1928. Las sentencias del Tribunal Supremo español se encuentran recopiladas en distintos repertorios de jurisprudencia, algunos de ellos digitalizados y de fácil consulta. Ahorro, pues, toda referencia a este respecto.

14 Después de una circular del fiscal general de la República de marzo de 1934, no había dudas acerca de que el art. 3.1 LVM mantenía la presunción de culpabilidad de "los que no justifiquen cumplidamente, siendo para ello requeridos por las Autoridades o sus Agentes autorizados al efecto, la legitima procedencia, adquisición y tenencia del dinero o efectos que se hallasen en su poder o que hubiesen entregado a otros para su inversión o custodia". Así lo ha indicado Carolina García Sanz, "Disciplinando al gitano' en el siglo XX: regulación y parapenalidad en España desde una perspectiva europea", Historia y Politica, n . 40, 2018, pp. 115-146, cita en p. 134. Disponible en linea: https://doi.org/10.18042/hp.40.05 (última consulta el 19/02/2020). 
han detectado casos análogos de discriminación de la comunidad merchera, lo que refleja hasta qué punto los prejuicios racistas podian haber calado en la burocracia policial y judicial ${ }^{15}$.

\subsection{Racismo inducido por el discurso judicial}

En un grupo de los sumarios y sentencias estudiadas se hablaba explícitamente de "gitanos" como categoría criminológica y cabe desgajar directamente ciertas repercusiones jurídicas de ello. En ocasiones, las alusiones constantes a "las Gitanas" y "los Gitanos" figuraban en las propias cubiertas de los rollos y piezas sumariales. Así, por ejemplo, el ramo de prisión provisional "del sumario por sustracción de caballerías contra los Gitanos Andrés Cabeza, Francisco Suárez y Antonio Vargas"16. Lo adjetivo iba por delante porque, sencillamente, no era adjetivo: estaba llamado a condicionar el curso de la actuación judicial. También la prensa conservadora se hacía eco de las detenciones de la Guardia civil poniendo por delante la pertenencia al grupo: "Gitano denunciado", podía leerse en los titulares ${ }^{17}$.

El robo de varias caballerias en Esparragosa de Lares (Badajoz) llevó a un juez de instrucción a procesar a un hombre y una mujer de etnia gitana oriundos de Andalucía ${ }^{18}$. Este proceso, inscrito en el segundo bienio de la República, nos permite rastrear algunas características $y$ consecuencias del estigma: desconfianza judicial y presunción de culpabilidad (se mandaba procesar "a unos Gitanos que dicen llamarse..."19); arrestos gubernativos irregulares y largas estancias de prisión provisional (más de una semana detenidos sin pronunciamiento judicial y tres meses de prisión preventiva); e incremento de la severidad penal (el escrito de calificación fiscal pretendía que se añadiera un delito de allanamiento de $\operatorname{morada}^{20}$ ).

El sumario no muestra la pena porque los acusados se dieron a la fuga, pero sí que aporta un dato interesante para entender la relación que los distintos estatus procesales tenían entre sí. Una mujer fue procesada y llegó a ser puesta en prisión provisional. Puesto que no consta que existieran pruebas palmarias ni que fueran capturados in fraganti, el tratamiento es indiciario de una relajación de la tutela judicial machista, la cual podía en un momento dado incidir de forma positiva en las mujeres, en lo que Lima Malvido ha llamado "la caballerosidad

15 A modo ilustrativo, citaré el arresto policial de varias "me[r]cheras" sobre la base de presunciones. El caso acabó en los tribunales, pero no porque existieran indicios de criminalidad contra las detenidas, sino porque éstas se resistieron e insultaron a la fuerza pública. Mientras que la detención arbitraria pasó desapercibida, se activó la lógica de la criminalización y del castigo sin condena. Sentencia de la Audiencia provincial de Barcelona de 5-XI-1931, sección 3ª . Ver el resultando $1^{\circ}$. ACTSJC, fondo Audiencia provincial de Barcelona (APBar de ahora en adelante), Libro de sentencias de 1931, t. 3, sig. 153.

\footnotetext{
16 AHPB, leg. 272, sumario $\mathrm{n}^{\circ}$. 1550/1935 y rollo $\mathrm{n}^{\circ}$. 762/1935.

17 “Gitano denunciado”, en El Día de Palencia, 18 de julio de 1931, p. 4.

18 AHPB, leg. 201, sumario nº 112/1933.

19 Auto de procesamiento de 14-X-1933.

20 Escrito de 7-II-1934.
} 
paternalista del sistema penal" 21 o lo que Lalinde Abadia ha identificado como las "compensaciones" experimentadas por las mujeres sumidas en un sistema androcéntrico y machista ${ }^{22}$. Combinándose el estatus de gitano y el de mujer, el segundo no desaparecía, pero mitigaba el primero. La hipótesis queda confirmada si se recuerda que, poco después, el juez de instrucción dictó un auto mandando que la mujer, y no el varón, fuera puesta en libertad provisional sin fianza ${ }^{23}$.

La secuencia se repite durante todo el período de vigencia del régimen constitucional. Un sumario incoado por el hurto de una mula y una yegua en Navalpillar de Pela (Badajoz) nos permite rastrear las mismas pautas judiciales en el primer bienio republicano ${ }^{24}$. En este caso, el atestado de la Guardia civil se refería a los presuntos culpables como "gitanos"25. La documentación judicial los clasificaba de un modo sui generis, lo que denota la versatilidad expresiva de un racismo institucionalizado y plenamente consciente: "de profesión gitano", se escribió ${ }^{26}$. Los procesados por este delito estuvieron tres meses en prisión provisional, algunos de los cuales en la prisión del Puerto de Santa María (Cádiz), lejos de la provincia en que fueron detenidos y en la cual residian ${ }^{27}$. En otros casos, la contextualización de los hechos enjuiciados parecía requerir la referencia a la presencia de "familias de gitanos" o la reunión de un "grupo de gitanos" en el lugar, como leemos en algunas decisiones de la Audiencia provincial de Barcelona ${ }^{28}$.

Algunas de las piezas de este bloque menguaban en explicitud pero pertenecían a una técnica común a todos los procesos de racialización y discriminación etnocultural y clasista que se observan en la justicia española del quinquenio republicano. La etiqueta podía descollar discretamente a modo de apodo en la identificación de los procesados que figuraba en el encabezado de las resoluciones judiciales ${ }^{29}$, o ya en los resultandos encargados de recoger los hechos probados ${ }^{30}$. Aunque los tribunales no tuvieran empacho en evidenciar la discriminación etiquetando a los procesados como "gitanos", no era menos

${ }^{21}$ María de la Luz Lima Malvido, Criminalidad femenina. Teorías y reacción social, Porrúa, México D. F., 1988, pp. 87-88 y 96.

22 Jesús Lalinde Abadía, Las culturas represivas de la humanidad (h. 1945), vol. II, Universidad de Zaragoza, Zaragoza, 1992, p. 723.

23 Auto de 8-II-1934. Sigo en AHPB, leg. 201, sumario nº 112/1933.

${ }^{24}$ AHPB, leg. 200, sumario $n^{\circ} .712 / 1932$.

${ }^{25}$ Ibid., p. 1

${ }^{26}$ Ibid., pp. 48, 60 y 67.

27 Ibid., pp. 16, 72, 74 y 80-82.

${ }^{28}$ En un delito de homicidio: sentencia de 1-II-1934. En un delito de atentado a la autoridad, juzgado por el tribunal de urgencia: sentencia de 6-II-1934. Ver resultando $1^{\circ}$ en ambos casos. ACTSJC, APBar, Libro de sentencias de 1934, t. 1, sig. 164.

${ }^{29}$ Sentencias de la Audiencia provincial de Sevilla $\mathrm{n}^{\circ} .198$ (3-XI-1931), nº 225 (27-IX-1933) sección $2^{\mathrm{a}}, \mathrm{n}^{\mathrm{o}} .127$ (4-IV-1936) sección $2^{\mathrm{a}}$, etc. AHPS, Libro de sentencias de 1931, Título 118 234, t. 2, sig. L-3195. Ibíd., Libro de sentencias de 1933, Título 1-345, sig. L-3110. Ibíd., Libro de sentencias de 1936, Título 1-333, sig. L-3119. Sentencia de la Audiencia provincial de Barcelona $\mathrm{n}^{\circ} .98$ (7-X-1933). ACTSJC, APBar, Libro de sentencias de 1933, t. 5, sig. 162. Sentencia de 13IX-1935. Ibid., Libro de sentencias de 1935, t. 5, sig. 174.

30 Sentencias de la Audiencia provincial de Barcelona de 28-X-1932 y 22-VII-1933, resultando $1^{\circ}$ en ambos casos. ACTSJC, APBar, Libro de sentencias de 1932, t. 4, sig. 157. Ibíd., Libro de sentencias de 1933, t. 4, sig. 161. 
frecuente que en el relato de los hechos probados se les atribuyeran expresiones como "parné"- para ofrecer una idea indirecta y al mismo tiempo clara sobre aquella categoría de subjetivación criminológica ${ }^{31}$.

\subsection{Racismo deducido del discurso judicial}

En otro bloque de casos son precisamente las repercusiones desventajosas las que permiten deducir el estatus, a pesar de quedar innominado, silenciado: el efecto da la pista sobre el sujeto gitano. Dentro de este conjunto, destacan dos líneas de actuación policial y judicial. Primero, podía llegarse a perseguir a sujetos clasificados expresamente como "morenos" sin que eso se circunscribiera a una inocente aproximación antropomórfica ${ }^{32}$. Entrarian aquí, en segundo lugar, aquellos supuestos en los que la identidad gitana pesaba de manera ineludible, bien porque brillaba o se infería de los datos personales de los procesados (apellidos, oficios, conducta, etc.), bien porque se desprendiese sin lugar a dudas de la presencia física de los mismos. Esto último es casi imperceptible en la documentación, aunque es posible que guardase un nexo estrecho con la forma de consignar los datos personales en el encabezado de las sentencias.

En este nutrido grupo de casos no se aprecia el estigma literalmente, aunque se deduce de algunas clasificaciones laborales y morales ${ }^{33}$, de las aproximaciones periciales a la edad ${ }^{34} \mathrm{y}$ del tratamiento procesal dado, desde el punto de vista de la prisión preventiva por ejemplo ${ }^{35}$. Habitualmente, la combinación razonable de algunos datos de los procesados -como sus apellidos- y ciertas tendencias interpretativas inusuales -como el énfasis supremacista en "la [baja] cultura del procesado"- permite entender por qué algunas sentencias no consideraban punibles algunas ofensas dirigidas contra los agentes de la autoridad: el racismo

31 Sentencia de la Audiencia provincial de Sevilla $\mathrm{n}^{\circ} .198$ (19-V-1936). La cita en el resultando $1^{\circ}$. AHPS, Libro de sentencias de 1936, Título 167-328, t. II, sig. L-3205.

32 En un caso del Juzgado de instrucción del distrito de la Magdalena (Sevilla), el individuo acusado de vender el mulo a un precio en desacuerdo con su valor real se defendió diciendo haberlo comprado a un "desconocido". Su prisión gubernativa comenzó el 5 de septiembre de 1933. El auto de prisión provisional no se dictó hasta cuatro días después, imponiéndole fianza de nada menos que 1.000 pesetas. Sufrió ese régimen durante un mes. AHPS, caja 7180, sumario 173/1933, pp. 1, 4, 8, 13-13 vo, 18, 21 y 31. Queda pendiente de estudio si existe un punto de conexión entre esta categoría y la de "morenos" que empezó a funcionar a partir de los siglos XVIXVII en numerosas ciudades andaluzas para designar a la población de ascendencia esclava. Ofrece noticia de ella Isidoro Moreno, La globalización y Andalucía. Entre el mercado y la identidad, Mergablum, Sevilla, 2002, pp. 121-122.

33 Así en la sentencia de la Audiencia provincial de Barcelona de 24-V-1932. ACTSJC, APBar, Libro de sentencias de 1932, t. 2, sig. 155.

$34 \mathrm{La}$ carencia de datos registrales de nacimiento y bautismo determinaba la intervención de facultativos para explorar la edad de los procesados. Esto era frecuente en poblaciones nómadas o marginadas, como las gitanas. Mientras tanto, se aplicaba la prisión provisional, sin que importase que la incertidumbre acerca de la edad repercutiese sobre la posible responsabilidad penal. AHPB, leg. 200, sumario nº. 712/1932, pp. 80-82.

35 Por ejemplo, largas estancias en prisión provisional para un "hojalatero" por hurtar caballerias sin violencia, intimidación ni fuerza, que fueron recuperadas para sus dueños, y una condena elevada, a un año y un día de presidio menor, accesorias y costas: sentencias de la Audiencia provincial de Sevilla $\mathrm{n}^{\circ} .263$ (10-VIII-1933) y $\mathrm{n}^{\circ}$. 130 (19-VI-1933) sección 2a. AHPS, Libro de sentencias de 1933, Título 221-449, t. II, sig. L-3199. Ibíd., Libro de sentencias de 1933, Título 1-345, sig. L-3110. 
antigitano poseía una vertiente paternalista ${ }^{36}$. Puesto que dicho trato era residual por regla general, supone un indicador de la existencia de particularidades; particularidades que no siempre pueden conocerse con certeza. Cuando retrotraemos la mirada atrás, a las distintas piezas del sumario, suele resultar fácil confirmar la hipótesis del peso del estigma de gitano, enunciada o no como tal en la sentencia definitiva, en atención a las clasificaciones morales y biopoliticas del individuo vertidas a lo largo de las pesquisas y, quizá, omitidas en la sentencia: según la Audiencia provincial de Córdoba Antonio Cortés Reyes (esquilador, soltero...) observaba "mala conducta moral pública y privada", era "de carácter díscolo y pendenciero", tenia "poco amor al trabajo", etc. ${ }^{37}$

Pese a la omisión del vocablo "gitano" para designar el estigma, en estos casos palpitaban las consecuencias negativas de dicho estigma con igual intensidad; por ejemplo, la presunción de culpabilidad y, subsidiariamente, el endurecimiento de las penas. Saquemos un caso de 1934 para ilustrarlo. Un gitano fue acusado de los distintos hurtos de caballerias que se produjeron en una misma noche. Sin duda, esa supuesta inclinación al delito sirvió de base para hacerle pasar por prisión provisional durante un mes. Al final, el fiscal sólo mantuvo la acusación en uno de los casos, solicitando que se aplicara la agravante por nocturnidad (art. 10.12 del código penal, CP), que la Audiencia de Sevilla aplicó encantada ${ }^{38}$.

La mayoría de las veces, las sentencias de instancia no mostraban con tanta desnudez como los atestados policiales la cuestión racista, lo que no quiere decir que no ocurriera así en ocasiones ${ }^{39}$. Predominaba el señalamiento del gitano por inferencia, es decir, la construcción discursiva del estatus de gitano sin mentarlo. Ahora bien, no puede ponerse en cuestión el afianzamiento de este racismo judicial a la luz de datos como éste. El Tribunal Supremo lo asumió, contribuyendo decisivamente a su reproducción. Ya he mencionado una sentencia de 1928 en la que el Alto Tribunal reflejaba las consecuencias penales de la presunción de culpabilidad de los gitanos. La doctrina criminal del régimen monárquico y dictatorial está repleta de nociones referentes a la etnia gitana de los procesados en todo tipo de delitos. Esto tenía lugar por dos vías principales: por arrastre de citas literales a las sentencias recurridas o por absorción de sus postulados en los resultandos y en los considerandos, respectivamente ${ }^{40}$. Lo sorprendente es que esto siguiera ocurriendo así bajo un régimen constitucional

36 Éste fue el argumento que utilizó la Audiencia provincial de Barcelona en su sentencia de 27-IV-1935 contra José Cortés Matamala, quien resultó absuelto del delito de injurias a la autoridad. ACTSJC, APBar, Libro de sentencias de 1935, t. 2, sig. 171.

37 AHPCo, caja 5541, sumario $n^{\circ} .90 / 1934$, p. 58.

38 Sentencia $n^{\circ} .278$ (3-VIII-1934) sección $2^{\text {a }}$. AHPS, Libro de sentencias de 1934, Título 266400, t. III, sig. L-3111.

39 Un caso por delito de resistencia a agentes de la autoridad: sentencia de la Audiencia hispalense $\mathrm{n}^{\circ}$. 124 (6-III-1934). Véase el resultando $1^{\circ}$. AHPS, Libro de sentencias de 1934, Título 1-311, t. I, sig. L-3200.

40 En el resultando $1^{\circ}$ de la STS $13-V I-1928$ se reproducía parte de la sentencia recurrida, la dictada por la Audiencia provincial de Murcia con fecha 6-XI-1927, en la que se identificaba a los procesados como "gitanos". Hacian este arrastre de estigmas las SSTS 25-VI-1928, 6-VI-1930 y 4II-1931. 
como el de la República, tanto en la esfera penal ${ }^{41}$ como en otras de nueva implantación, como podría ser la laboral ${ }^{42}$.

Algunos sumarios muestran la presencia transversal a autoridades, tanto policiales como judiciales y fiscales, de esta forma de discriminación ${ }^{43}$. Si la continuidad del personal judicial y policial podría justificar la continuidad del discurso racista, lo cierto es que las autoridades gubernativas nombradas por la República tampoco rompieron con la pauta 44 . Por lo tanto, no hay razones para dejar de descartar factores meramente casuales o circunstanciales a la hora explicar el tratamiento discriminatorio de la población romaní. En caso contrario, si limitáramos el estudio a casos de racismo flagrante, estariamos apartando del campo de visión un condicionante estructural de tanta magnitud para la implantación y el desarrollo del constitucionalismo en España, como éste del racismo institucional. El hecho de que el discurso racista anti-romaní gozara socialmente de cierta hegemonía, remarcando la tendencia de la comunidad gitana a delinquir y dibujando a sus miembros como los principales sospechosos de cualquier crimen ${ }^{45}$, no resta importancia al carácter anticonstitucional e ilegitimo de la adhesión y promoción de dicho discurso por las autoridades e instituciones estatales. La memoria publicada por el fiscal general sobre el año 1932 -una de las más coherentes con el modelo constitucional republicano- se hizo eco de algunos prejuicios y estereotipos perniciosos para la población romani ${ }^{46}$.

El análisis de la repercusión punitiva concreta que la categoría de gitano desplegaba sobre el razonamiento judicial es posible sin entrar en el terreno de las especulaciones. Estudiemos tres casos tomados del fuero común y el militar. Respecto al primero, veamos un par de sentencias de 1936 redactadas por el mismo magistrado ponente de la Audiencia provincial de Sevilla, Antonio Fernández Gordillo. En la primera, de 6 de febrero, la afirmación literal de que el procesado era "de raza gitana" tuvo un efecto positivo para el mismo, pues dio pie a que se aplicaran las circunstancias atenuantes de los arts. 9.2 y $9.5 \mathrm{CP}$, toda vez que la agresión de la que el acusado fue autor estuvo provocada previamente por la víctima. El encartado le golpeó con un palo después de que aquella "empezara a mofarse de los gitanos"47. La segunda sentencia se publicó estando

41 SSTS 19-X-1931, 16-X-1933, 19-X-1934, 5-II-1936, 20-II-1936 у 2-IV-1936.

42 Sobre accidente de trabajo, con mención gratuita a la etnia gitana: STS 21-X-1931.

43 AHPS, caja 5586 (2/3), sumario 8/1934, pp. 4-6 para los atestados de la Guardia civil y p. 13 para auto judicial enfatizando la condición de "Gitano".

44 Para una "reyerta entre gitanos" de la que resultaron cuatro muertos en el concejo de Quejana, localidad de Ayala (Vitoria): AHN, fondo Ministerio de la Gobernación (MG en adelante), serie A, leg. 16/2, exp. 16, $\mathrm{n}^{\circ}$. 2, telegrama oficial del gobernador civil de Álava al ministro de la Gobernación (24-VI-1931).

45 “¡Cosas de gitanos!”, en Crónica Meridional (Almería), 29 de mayo de 1931, p. 5.

46 Recogía que el fiscal de Granada se quejaba de la "vagancia ininterrumpida" de los reclusos en la prisión provincial, añadiendo que, "paradójicamente, sólo rompen esta nota de ociosidad los gitanos". Gabriel Martínez de Aragón y Urbiztondo, Memoria elevada al Gobierno de la República con motivo de la solemne apertura de los tribunales el dia 15 de septiembre de 1932, Madrid, Reus, 1932 , p. 18.

47 Sentencia $n^{\circ} .63$ (6-II-1936), sección $2^{a}$. Cita en resultando $1^{\circ}$. La idea de estimar la atenuación de la responsabilidad criminal provino del Ministerio fiscal. AHPS, Libro de sentencias de 1936, Título 1-333, sig. L-3119. 
ya el Frente Popular en el gobierno, y ahonda en el tutelaje racista de cuño colonial que ya muestra la anterior. Flotaba en el aire una condena por tenencia ilícita de arma de fuego. Al final, el fallo fue muy generoso: sólo dos meses y un día de arresto mayor, pese a que el reo llegó a disparar la pistola hiriendo a una persona. Para ello fue necesario demostrar que el sujeto no era peligroso y, con ello, que carecía de malicia, entendiendo por tal tanto la ausencia de intención de matar como la ausencia de motivación política o social. En caso contrario, la condena podría haber alcanzado hasta dos años de reclusión. El tribunal no encontró mejor fórmula para comprobar ambas cosas que reducir los hechos a una "riña de gitanos" 48. El paternalismo supremacista -con efectos paradójicamente favorables en algunos casos- es la punta de iceberg de la inferiorización acometida sobre el colectivo.

La represión penal de los gitanos era más dura en otros supuestos, lo que dificulta la detección de una pauta que no fueran los prejuicios de los jueces. El segundo tipo a valorar se concreta en el encarcelamiento preventivo de gitanos sin que se estableciera ningún nexo de proporcionalidad entre la acusación y la medida cautelar, sólo con el ánimo de escarmentar. Por el hurto de una burra en Utrera (Sevilla) se hizo sufrir más de dos años de prisión provisional a un gitano, no nombrado como tal en la sentencia. Pendía sobre él un escrito de acusación fiscal que se limitaba a dos meses de arresto, por lo que llegado el juicio oral pareció razonable mostrar la conformidad con la acusación y ser puesto cuanto antes en libertad ${ }^{49}$. Nueve meses estuvieron presos preventivos otros dos gitanos, por el mismo motivo, hasta que fueron absueltos por "falta material de pruebas"50.

Por último, el estatus procesal de gitano también tenía eficacia en la jurisdicción castrense. Puede ilustrarse con un sumario iniciado en verano de 1934 para esclarecer los motivos por los que un guardia civil había causado dos heridas de bala a un paisano ${ }^{51}$. Resultó probado que la Guardia civil detuvo a dos sujetos sospechosos de cometer el delito de hurto de caballerías en las inmediaciones de un cortijo de Morón de la Frontera, en la provincia de Sevilla. Curiosamente, ha quedado recogida la misma expresión para referirse a ellos en los atestados de la Guardia civil, en las declaraciones de los agentes participantes y en las de algunos testigos, entre los que se hallaban guardas jurados de fincas privadas: "sugetos de aspecto jitanos y sospechosos" 52. A lo largo de la instrucción de las diligencias previas el juez militar usó la misma categoría: "jitanos de aspecto sospechoso" 53, lo que hace intuir cierta predisposición formularia del proceso. De acuerdo con las distintas versiones, el herido intentó

48 Sentencia $n^{\circ} .181$ (12-V-1936), sección $2^{\mathrm{a}}$. Resultando $1^{\circ}$. Ibíd.

49 Sentencia $n^{\circ} .543$ (22-XI-1934). El acusado venía descrito en los siguientes términos en el encabezado: "de oficio cargador y del campo, mala conducta, insolvente, con instrucción, sin antecedentes penales". Los apellidos hacían innecesario aludir a la condición gitana: Lara Montoya. AHPS, Libro de sentencias de 1934, Título 312-616, t. I, sig. L-3201.

50 Canastero y jornalero, fueron los dos etiquetados como sujetos de mala conducta, sin instrucción, insolventes y sin antecedentes penales. Sentencia n ${ }^{\circ}$. 610 (28-XII-1934). Ibid.

51 AHTMTS, fondo República, leg. 163, nº. 1540, causa nº. 133/1934.

52 Ibid., pp. $3 \mathrm{v}^{\mathrm{o}}, 19$, etc.

53 Dictamen elevado al auditor, 14-VI-1934. Ibíd., p. 14. 
huir -por temor a ser maltratado según su relato ${ }^{54}$ y la pareja de la Guardia civil le disparó en dos ocasiones después de algún que otro tiro "al aire"55. Pues bien: el gitano curó de las heridas y denunció a los agentes.

Las diligencias previas fueron elevadas a sumario, cambiando de manos la instrucción. El nuevo juez militar barrió el léxico discriminatorio difundido hasta entonces. Pero la supresión consciente del factor textual no significó la desaparición del hecho de la discriminación ni borraba, por supuesto, la complicidad de las autoridades judiciales con el uso desmedido de la fuerza. Sencillamente, donde ponía "jitano" pasaba a leerse "paisano", pero el fondo de la argumentación no varió. Se pretendiera ocultar de manera consciente o no, la investigación siguió un derrotero tendente a hacer prevalecer la impunidad de los agentes por el delito de lesiones perpetrado. Al elevar su dictamen al auditor se lubricó el camino al sobreseimiento: "no se ha podido proceder contra nadie", concluía ${ }^{56}$. El auditor decretó en consecuencia. El sumario debía sobreseerse con carácter definitivo porque el guardia civil que apretó el gatillo actuó en cumplimiento de sus deberes reglamentarios y bajo las órdenes del jefe de la pareja, lo que le eximía de responsabilidad ${ }^{57}$. La interpretación de siempre ${ }^{58}$.

\subsection{Gitanidad, nación y República}

En sintesis, el para-derecho anti-romaní era una variante contrastada en la historia de lo jurídico del más amplio derecho de coacción del otro interior a la nación-Estado. Como tal manifestación de lo que Rita Laura Segato ha calificado gráficamente como el "totalitarismo de nación"59, el para-derecho anti-romaní subsistió durante la Segunda República, esto es, durante la vigencia del Estado constitucional. Lo hizo, además, conservando muchos de los rasgos característicos del régimen inmediatamente anterior y su densa tradición ${ }^{60}$.

En primer término, se siguió persiguiendo con notable insistencia la sustracción de caballerías con los mismos efectos que en el último cuarto del siglo XVI: compeler al asentamiento de las familias gitanas y envolver de

${ }^{54}$ Ibid., pp. $13 \mathrm{v}^{\mathrm{o}}-14$ y 24.

55 Ibid., p. $3 \mathrm{v}^{\mathrm{o}}$.

56 Dictamen del juez instructor, 5-VII-1934. Ibid., pp. 38-39.

57 Decreto del auditor, 14-VII-1934. Ver considerandos $1^{\circ}$ y $2^{\circ}$. Ibid., pp. 40-40 vo .

58 El mismo razonamiento fue frecuente y unánime durante la monarquía. Para el delito de lesiones graves ocasionadas a un sospechoso de hurto de caballerias, también en Sevilla: decreto del auditor general de la $2^{\text {a }}$ Región de 20-VIII-1920. AHTMTS, fondo Alfonso XIII, leg. 76, $\mathrm{n}^{\circ}$. 527, causa sin número visible incoada el 29-I-1920, pp. 74-75. A propósito del homicidio de un campesino a manos de la Guardia civil en Espera (Cádiz): decreto del auditor de 24-IV-1913. Ibid., leg. $31, \mathrm{n}^{\circ}$. 186 , causa $\mathrm{n}^{\circ} .2058 / 1912$, pp. $156 \mathrm{v}^{\circ}-157 \mathrm{v}^{\circ}$. Podrían citarse numerosos ejemplos del período republicano. Uno tomado de Córdoba, llamativo porque pese a imputarse al paisanaje una despiadada agresión previa, sólo caían heridos y muertos dentro del mismo: AHTMTS, fondo República, leg. 149, nº. 1399, causa nº. 87/1934, p. 63.

59 Rita Laura Segato, La guerra contra las mujeres, Traficantes de Sueños, Madrid, 2016, p. 49.

60 Una aproximación a las raíces históricas del discurso anti-gitano en la modernidad/colonialidad española: Helios F. Garcés, "El racismo antirom/antigitano y la opción decolonial”, Tabula Rasa, $\mathrm{n}^{\circ}$. 25, 2016, pp. 225-251. Disponible en línea: http://www.revistatabularasa.org/numero-25/08Garces.pdf (última consulta el 19/02/2020). 
seguridad jurídica el tráfico de animales ${ }^{61}$, que seguía siendo el principal medio de trabajo y tracción en una economía eminentemente agraria y poco mecanizada como la de la España de los años treinta. Tampoco varió en demasía, pues, el propósito de las autoridades públicas. La antedicha presunción de culpabilidad hacía viable a los tribunales el castigo del sospechoso de hurto o robo incluso cuando no había asideros fehacientes acerca de la responsabilidad penal directa. La presunción forzaba la interpretación del encubrimiento: el castigo en concepto de encubridor de un hurto cuya comisión se consideraba probada, pero no su autoria, posibilitaba el castigo impropio y por subterfugio del sospechoso, erigido así a la condición de culpable vicario ${ }^{62}$. Por lo tanto, la presunción históricopositiva de culpabilidad poseía traducción judicial en los años republicanos.

En segundo lugar, el énfasis textual en la gitanidad y la definitiva constitución judicial de un estatus del justiciable gitano no connotó una tendencia retórica universal que afectaba a cualquier gitano que se veía inmerso en un proceso judicial. El hecho de que este discurso se diera en unos casos y no en otros deja entrever, antes que el progresivo desvanecimiento de su vigencia, cuál era su verdadero sentido político histórico. No se trataba de estigmatizar a todo gitano que pasara por los tribunales o que se cruzara con un agente de la autoridad. Gitanos habia -y en ocasiones puede intuirse con solvencia debido a sus apellidos, oficios, domicilios, etc.- que eran encartados sin que ninguna evidencia documental, ni formal ni sustantiva, haga pensar que esa condición resultara relevante a efectos judiciales. La intermitencia del discurso racista no quiere decir que éste declinase con el régimen constitucional republicano. Al contrario, da cuenta de su destinatario, del concreto segmento del colectivo al que se dirigía.

Así, también, el discurso judicial racista da pistas del emisor y sus propósitos. Para aprehender bien en los años treinta lo que Sebastián Martín ha denominado el "enemigo racial" del Estado español ${ }^{63}$, es preciso puntualizar que el discurso estigmatizador anti-romaní era lanzado contra aquellos otros gitanos que realmente eran diferentes a la imaginaria y pretendida homogeneidad de la comunidad social y nacional. Se coaccionaba a aquellos gitanos que, en otras palabras, eran "otros". Para los gitanos no asimilados que vivificaban la otredad se diseñó el discurso judicial y policial anti-romaní, lo que -bien es ciertorequería como condición de posibilidad que se emplease contra todos los gitanos prima facie y en general. Este aspecto, que pudiéramos percibir como una timidez clasificatoria en un ataque de ingenuidad, no denota un incremento de la

${ }^{61}$ Antonio Gómez Alfaro, "Sobre la historia de los gitanos de Extremadura", I Tchatchipen, $\mathrm{n}^{\circ}$. 98, 2017, pp. 4-18, ver p. 7. El mismo autor ha reunido un valioso repertorio normativo sobre la discriminación anti-romaní: Legislación histórica española dedicada a los gitanos, Consejería de Igualdad y Bienestar Social-Junta de Andalucía, Sevilla, 2009.

62 Un ejemplo: la sentencia de la Audiencia provincial de Sevilla $\mathrm{n}^{\circ}$. 146 (11-IV-1936). El castigo por encubrir un delito de hurto implicaba multa de 250 pesetas de multa, o en su defecto arresto sustitutorio de dieciséis dias. AHPS, Libro de sentencias de 1936, Título 1-163, t. I, sig. L3204.

63 Sebastián Martín, "Criminalidad politica y peligrosidad social en la España contemporánea (1870-1970)", Quaderni fiorentini per la storia del pensiero giuridico moderno, vol. 38, nº. 1, 2009, pp. 861-951, cita en p. 870. 
complejidad de los dispositivos racistas al calor del Estado constitucional, sino la continuidad de una forma de discriminación y etnocidio ya conocida ${ }^{64}$.

A este respecto se ha dicho, desde la historia de la ciudadanía, que los gitanos han sido convertidos en "una parte esencial del cuerpo simbólico de la nación española" después de un largo proceso político y cultural que ha orillado la realidad de sus "cuerpos no simbólicos y sus problemas"65. A mi modo de ver, el problema en la construcción de la nación española, incluso en tiempos de la reformulación republicana, consistía en cómo integrar esos cuerpos vivientes en la comunidad. Los gitanos asimilados podian seguir siendo gitanos como cuerpos simbólicos y, en este sentido, compatibles y útiles para la identidad nacional ansiada. Pero los gitanos-cuerpos vivientes siguieron siendo objeto de castigo por la amenaza que entrañaban a la idea de España según la entendían las oligarquías que manejaban los resortes coactivos del Estado. La represión judicial de los gitanos en 1931-1936 pone de manifiesto la singular autonomía de los cuerpos judiciales, policiales y militares respecto al proyecto de Estado constitucional y sus exigencias.

Ciertamente, el artefacto era "clásico". La poca deferencia prestada a los gitanos, traducida en una falta de menciones en las normas escritas que contrastaba con la relevancia práctica en la aplicación del derecho, hundía sus raíces en el "doble supuesto" del constitucionalismo colonial, según lo ha definido Bartolomé Clavero. Por un lado se consideraba a los indígenas parte de la ciudadanía, pero por otro se les deparaba una tutela hasta que no abandonasen sus marcadores identitarios, las "lenguas y costumbres propias". Así se "producía el efecto de excluir incluyendo, o incluir excluyendo" en los albores coloniales del constitucionalismo ${ }^{66}$. Lo mismo se observa en el tratamiento constitucional en sentido material otorgado a los gitanos en época de la República, que las autoridades judiciales, policiales y militares no sólo reprodujeron sino que produjeron. Pues sólo los gitanos que poseían estilos de vida claramente distintivos eran objeto de un tratamiento discriminatorio por parte del derecho aplicado $^{67}$. De ahi la modalidad incruenta y selectiva de persecución de la etnia romaní, que no da cuenta sino de una movilidad relativa pero promocionada desde el poder, en el sentido de que las instituciones buscaban la asimilación no niveladora de dicho grupo. Era un pulso a lo que Marvin Harris llamó "capacidad adaptativa" de la minoria: el favorecimiento de la exogamia y la difuminación de los marcadores de identidad gitana, empero, constriñendo la confusión con el

64 En el siglo XVIII el discurso jurídico sólo atacaba a quienes no abandonaban "trage, lengua y modales"; los demás debían ser tratados "como a cualesquiera vecino". Antonio GómEZ ALFARO, "Sobre la historia de los gitanos de Extremadura", op. cit., p. 15.

65 Maria Sierra-Alonso, "Cannibals Devoured: Gypsies in Romantic Discourse on the Spanish Nation", en María Sierra (ed.), Enemies Within. Cultural Hierarchies and Liberal Political Models in the Hispanic World, Cambridge Scholars Publishing, Cambridge, 2015, pp. 187-221, cita en p. 214.

66 Bartolomé Clavero, El orden de los poderes. Historias Constituyentes de la Trinidad Constitucional, Trotta, Madrid, 2007, pp. 228 y 260.

67 Un tratamiento discriminatorio estrictamente debido a su condición gitana, pues con independencia de ésta podian sufrir cualquier otro estigma judicial (extremista, separatista, mujer, etc.). 
imaginario de clase trabajadora, en la que mayoritariamente se integraba la etnia gitana 68 .

La categoría genérica de "gitano" fue construida mucho antes del período jurisprudencial correspondiente a los años republicanos. Por consiguiente, aunque en su origen consistiera básicamente en un artilugio de identificación externa de aquellos sujetos sobre los que se aplicaba, puede decirse que en la década de 1930 constituía ya una identidad desde dentro, esto es, asentida por sus destinatarios, con o sin reapropiación mediante un ejercicio de redefinición crítica. Este aspecto es secundario a los efectos de este trabajo. Lo que importa subrayar es que la tacha de "gitano" no se extendia a todos los miembros de la etnia romaní, sino sólo a los visiblemente reconocidos como tales. Estos segundos sujetos tenian un estatus procesal mermado en derechos de defensa, cuya consecuencia era una capacidad jurídica y de obrar minimizada, que le hacía oscilar entre, por un lado, la anti-ciudadanía de aquellos sujetos expulsados del régimen de derechos liberal y republicano (vagos y maleantes) ${ }^{69} \mathrm{y}$, por otro, la sen-ciudadanía o a-ciudadanía de quienes realmente elegian vivir al margen de ese marco jurídico estatal y sólo resultaban introducidos, en calidad de inferiores, en la hora policiaco-punitiva (un ejemplo extremo: los gitanos y los nómadas sin registrar por ninguna administración y hablantes del idioma caló, o los mercheros itinerantes).

No hay que confundir esta construcción judicial de estatus con un reconocimiento de la etnia romaní. Incluso cuando se torna difícil desentrañar el impacto concreto del etiquetado de tal gitano en un litigio, la noticia es jurídica y constitucionalmente trascendental, pues no deja de dar cuenta de la existencia de un proceso permanente de identificación racial francamente hostil y dirigido por las instituciones policiales, militares y judiciales. No es casualidad que se optara por el apelativo, elevado a estigma, de "gitano", y que se negase cualquier espacio de autonomía comunitaria o no susceptible de anexión por la instancia estatal. El registro de la diferencia étnica en el lenguaje judicial y policial vaciaba los contenidos verdaderos del factor diferencial a nivel étnico, religioso, ideológico, moral, etc. Así era como anulaba los antagonismos subyacentes o potencialmente derivados de la gitanidad. Por ende, la clasificación ius-antropológica era una pieza clave en la politica de la identidad llevada a cabo por el aparato de Estado español, autoritario hasta la médula; a decir verdad prácticamente el único Estado español existente. A la vez, era un soporte del nacionalismo de Estado que no el nacionalismo republicano- y, como tal, tanto una búsqueda de la dominación de los grupos sometidos como una búsqueda de cohesión de los grupos rectores, en cuyo seno las clasificaciones procesales ayudaban a

68 Marvin Harris, Antropología cultural, Alianza, Madrid, 20113, traducción de Vicente Bordoy y Francisco Revuelta, pp. 360-361.

69 Véanse dos casos contra individuos de etnia gitana: ARCG, fondo 008JII1GR, caja 27970, pieza 2. exp. s/n. El expediente se encuentra sin paginar. ARCG, fondo 00JII1GR, caja 35603, pieza 3, exp. 8, pp. 31-31 v . Consúltese en este segundo caso la sentencia de la Audiencia provincial de Granada $n^{\circ}$. 6 (14-X-1935), sección 2 $2^{a}$, en la resolución del recurso de apelación interpuesto por el condenado en la primera instancia. La resolución confirmaba la sentencia recurrida, aunque reducia el tiempo máximo de las medidas de seguridad impuestas por el juez instructor en sentencia de 10-X-1935. Entre los hechos probados, se destacaba la "detestable conducta" del procesado. 
configurar las relaciones de competencia por el poder con arreglo a patrones no exclusivamente económicos.

El proyecto de institucionalización republicana del Estado planteado en 1931 chocó con esta lacra funcional, radicalmente vigente según hemos cotejado en una muestra significativa de prácticas policiales y judiciales. Este modo de pensar y de actuar de una parte de la administración, la cual detentaba una porción considerable de poder, había de formatear de modo decisivo cualquier proyecto de ciudadanización y nacionalización. Su estudio nos ha dado a conocer algunos puntos ciegos del proyecto republicano, no sólo los poderes reales detentados por la magistratura en cuanto al acceso de los ciudadanos a los derechos. La república fue haciéndose cada vez más pequeña para la República.

Además, la cuestión gitana fue invisible a ojos del movimiento obrero, principal fuerza de impulso del proyecto reformista que fue la República. Con una orientación política dispar a aquel, parece que sólo en las arenas del anarquismo y el comunismo se pudieron dar algunos pasos, tímidos, en la apreciación de las peculiares relaciones de explotación y alienación de que el colectivo gitano era víctima $^{70}$. Resulta paradigmática a este respecto la figura de Helios Gómez, artista gitano andaluz perseguido por sedición durante el primer año republicano ${ }^{71}$. En ocasiones, los abusos de la autoridad contra los gitanos sirvieron de pretexto para que obreros anarquistas se enfrentaran a las fuerzas de orden público, como ocurrió en Bujalance (Córdoba) durante la huelga campesina de noviembre de 1931, si bien en casos como éste la determinación del paro predisponía al enfrentamiento ${ }^{72}$. Definitivamente, la cuestión de clase $-\mathrm{y}$ la identidad de clase- se superponía sobre la étnica, lo que también acaecía en el terreno sexual o de género.

\section{MOROS}

La dominación colonial de España sobre el Norte de África tuvo diferentes expresiones juridicas y judiciales que abrigaron una lógica racista de gran trascendencia para el régimen constitucional republicano. De acuerdo con la definición dada por aquellos años del colonialismo como "una sanguijuela de dos ventosas" 73, intentaré realizar un recorrido circular por las vicisitudes de esa lógica dentro y fuera de la Península.

70 Por ejemplo, murió un anarquista gitano durante la quema de conventos producida en mayo de 1931 en Madrid. "Tranquilidad completa en Madrid", en El Adelanto (Salamanca), 14 de mayo de 1931, p. 4.

71 AHPS, caja 3302, relación de sumarios que se sustancian en el Juzgado de instrucción del distrito de San Vicente (Sevilla) que llevan más de dos meses de tramitación. Según consta, Gómez se encontraba procesado junto a otros en el sumario n ${ }^{\circ} .306$ incoado el 7-VIII-1931. Una providencia de 1-IX-1932 recordaba al comisario de policía pertinente que estaba pendiente su busca y captura. Me ha sido imposible localizar el sumario.

72 "Gobierno civil" y "Graves sucesos en Bujalance", en Diario de Córdoba, 14 de noviembre de 1931, p. 1. "Un hombre muerto y seis heridos", en Política (Córdoba), 14 de noviembre de 1931 , p. 3.

73 Ho Chi Min, “La URSS y los pueblos coloniales” (1924), en Selección de escritos politicos, Ediciones La Rosa Blindada, Buenos Aires, 1974, pp. 117-121, cita en p. 117. 
Marruecos quedó al margen de la Constitución de $1931^{74}$. Un libro de complemento del Manual del Interventor editado por la Alta Comisaria años atrás se justificaba a si mismo en la "experiencia del tiempo servido en la Zona del Protectorado (...) cerca de los indígenas"75. El punto de partida de la obra es significativo: autoridades militares que habian servido en las fuerzas de ocupación colonial durante la dictadura de Primo e incluso antes se aprestaban a dar directrices a sus compañeros en tiempos de régimen constitucional y democrático. La Constitución republicana llevaba un año vigente cuando se publicó un opúsculo destinado a perpetuar los dispositivos racistas de control y disciplina de la población indígena. La acción española era definida en términos de "administración" e "intervención". En virtud a la primera función, la Alta Comisaría, como representación suprema del gobierno de la "Nación protectora", asumia funciones en todo lo relativo a materias como colonización, obras públicas, sanidad, enseñanza hispana, recaudación de impuestos, etc. Con arreglo a la "intervención", la Alta Comisaría debía intervenir por medio de interventores y demás funcionarios, tanto civiles como militares, en todos los actos gubernativos y judiciales realizados por las autoridades indígenas, en régimen de "constante tutela" 76 . Según sus palabras, el servicio de intervención estaba guiado por "la necesidad de asegurar una continuidad de método en la obra interventora" 77 .

Los requisitos del interventor para ser un "verdadero misionero" de la civilización eran puramente culturales y morales: "ser arabista, honrado, ingenioso, discreto, bien educado y sobre todo comprender el alma indígena conservando al moro, no como un ser inferior y sí como un amigo o más bien como un hermano menor al que hay que tutelar hasta su mayor edad". Entre otros consejos, el siguiente: ya que los interventores reunian funciones judiciales y gubernativas de hecho, "si mostráis vuestra indulgencia que a ella preceda el castigo"78. Y una cautela por encima de cualquier otra: desconfiar siempre de la existencia de algún "tipo de "moro bueno". Solía ser un farsante ${ }^{79}$.

La tensión entre praxis institucional y normatividad constitucional es más aparente que real. La primera hornada de Estados constitucionales de Europa -y el español en este caso- no eran ajenos a la problemática colonial, sino cómplices

\footnotetext{
74 Sobre la esencial coherencia en la politica colonial llevada a cabo por la República, aunque centrado en el primer bienio: Luis V. Pérez Gil, Análisis de la politica exterior de los estados. Su aplicación a las relaciones exteriores de España durante el bienio republicano-socialista (1931-1933), tesis doctoral, Universidad de La Laguna, San Cristóbal de La Laguna, 2000. Disponible en línea: http://riull.ull.es/xmlui/handle/915/9990 (última consulta el 19/02/2020). Sobre la significación del silencio guardado por la Constitución de 1931 en cuanto a la cuestión colonial: Bartolomé Clavero, "Derecho bajo asedio, 1936-1939. República española y Sociedad de Naciones en el escenario europeo entre constitucionalismo y dictadura", Quaderni fiorentini per la storia del pensiero giuridico moderno, vol. 47, nº 1, 2018, pp. 257-315, especialmente pp. 273-274 y 276.

75 Coronel Capaz, comandante Galera y capitán Ochoa Iglesias, Asuntos indigenas. Orientaciones a los interventores en la labor del Protectorado en Marruecos, Tip. La Provincia, Las Palmas de Gran Canaria, 1932, p. 3.

76 Ibid., pp. 5-6.

77 Ibid., p. 24.

78 Ibid., pp. 12-13.

79 Ibid., pp. 14-15.
} 
de la misma por mantener vivo el "estándar de civilización" asumido del siglo $\mathrm{XIX}^{80}$. El gobierno de Azaña aprobó el 26 de diciembre de 1931 un decreto referente a la organización del protectorado pocas semanas después de que la Constitución viera la luz, sin que cupiera mención alguna al nuevo orden constitucional: ni en el articulado ni en la exposición de motivos ${ }^{81}$. La yuxtaposición del Estado constitucional y sus postulados al Estado preconstituido y sus inercias operativas tuvo un impacto directo en el área de los derechos ciudadanos y de las personas.

Aunque el citado decreto de diciembre abogara por una desmilitarización progresiva (art. 3) ${ }^{82}$ e insinuara la independencia de la administración de justicia (art. 4 in fine) ${ }^{83}$, aquella apenas avanzó y el núcleo de derechos constitucionales atribuidos a los españoles -lo que el art. 6.3 agrupaba como el "régimen de las colonias europeas" y el "ejercicio de los derechos de asociación y reunión, pasaportes, inmigración, trabajo y cuestiones obreras y sindicales"- estaban sometidos al ámbito competencial de la Secretaría de la Alta Comisaría, es decir, la autoridad gubernativa. Se imponía la excepción colonial en tiempos de Constitución normativa -incluso- en perjuicio del pueblo colonizador ${ }^{84}$. Cuando el decreto de 1931 fue sustancialmente reformado cuatro años después bajo el gabinete de Alejandro Lerroux, esos déficits de constitucionalidad se acentuaron $^{85}$. No extraña, pues, la observación realizada por los anarquistas en

80 Sebastián Martín, "El orden jurídico europeo de 1918-1945”, en Marta Lorente Sariñena y Jesús Vallejo Fernández de la Reguera (coords.), Manual de historia del derecho, Tirant lo Blanch, Valencia, 2012, pp. 527-572.

81 Decreto relativo al Protectorado en la zona de influencia española en Marruecos, GM, $\mathrm{n}^{\circ}$. 365, 31 de diciembre de 1931, pp. 2002-2004.

82 Se preveía la división de la Zona española de Protectorado en "regiones civiles" y "regiones militares", según criterios geográficos y el "mayor o menor grado de pacificación" de las kabilas. A este respecto, véase José Luis Villanova, "La organización territorial del Protectorado español en Marruecos", Revista de Estudios Internacionales Mediterráneos, 9, 2010. Disponible en linea: https://revistas.uam.es/index.php/reim/article/view/833/821 (última consulta el 19/02/2020). Sobre las dificultades desatadas por las medidas desmilitarizadoras tomadas por Azaña: Sebastian Balfour, Deadly embrace. Morocco and the Road to the Spanish Civil War, Oxford University, Oxford, 2002, pp. 243-247, y José Luis Villanova, "La pugna entre militares y civiles por el control de la actividad interventora en el Protectorado español en Marruecos (1912-1956)", Hispania, vol. LXV/2, $\mathrm{n}^{\circ}$. 220, 2005, pp. 683-716, ver pp. 708-711. Disponible en linea: https://doi.org/10.3989/hispania.2005.v65.i220.146 (última consulta el 19/02/2020).

$83 \mathrm{El}$ tenor literal del precepto daba pistas de la posición subalterna del poder judicial: "La Administración de Justicia forma también parte del Protectorado, pero sin constituir un órgano de la Alta Comisaria".

84 En lo concerniente al derecho del trabajo, arribó a Marruecos "una traslación muy aminorada y sesgada de los grandes avances" que se producian en la metrópolis -por ejemplo, en materia de jornada laboral-, y sólo en provecho de trabajadores españoles, europeos y protegidos. Las reformas republicanas de 1932 a propósito de los accidentes de trabajo no se extendieron a Marruecos hasta marzo de 1936. Josep Cañabate Pérez, "La exportación de derecho del trabajo al protectorado español en Marruecos (1912-1956)", IusLabor, nº 1, 2016, pp. 6 y 10. Disponible en linea: https://www.raco.cat/index.php/IUSLabor/article/view/307088 (última consulta el 19/02/2020).

85 Decreto disponiendo que la acción de España en Marruecos se ejercerá por un Alto Comisario, GM, nº 48, 17 de febrero de 1935, pp. 1397-1399. Desapareció la mención al estatuto jurídico de los colonos y trabajadores españoles al mismo tiempo que se afianzaba la fusión y centralización de las denominadas Intervenciones civiles y militares de España en Marruecos. 
1938, cuando sostuvieron que la Zona española del Protectorado funcionó con la República igual que con la monarquía: las libertades de enseñanza y prensa, y derechos como el de reunión y manifestación, fueron "derechos negados, sistemática y estúpidamente" por todos los ejecutivos ${ }^{86}$.

El recorte de derechos de la población española perseguía asegurar la exclusión rotunda en el caso de la población autóctona. Correspondió su perfilamiento al Tribunal Supremo, en un ejemplo patente de asunción de tareas palpablemente constitucionales por un órgano jurisdiccional ajeno al Tribunal de Garantías Constitucionales incluso cuando éste ya se hallaba a pleno rendimiento. La Audiencia de Tetuán condenó en sentencia de 14 de noviembre de 1934 a un grupo de españoles como autores del delito de asociación ilícita. Habian fundado el Partido Comunista en Larache y venian repartiendo propaganda contraria a los "principios básicos del Protectorado", llegando a preconizar "el abandono por España de Marruecos". Se les impuso un año de prisión. El tribunal de instancia había aplicado la normativa penal especial que regía para los paisanos españoles residentes en Marruecos: el reglamento aprobado en el dahir de 24 de diciembre de 1931, que definía el delito de asociación ilícita en los arts. 22 y $23^{87}$.

Los condenados interpusieron recurso de casación por infracción de ley fundándose, básicamente, en que la propaganda favorable a la salida de España no dificultaba su acción como protectora. El Tribunal Supremo falló sin tener en cuenta absolutamente para nada el régimen de derechos y garantias constitucionales. La excepción a la Constitución era absoluta; no tenía entrada en el razonamiento ni a modo de criterio hermenéutico. Al contrario, era el sistema constitucional el que debía ser interpretado a tenor de "los compromisos internacionalmente contraídos" por España en cuanto a las funciones de protectorado. En este punto el Alto Tribunal no quiso desaprovechar la oportunidad de hacer gala de españolismo y antipositivismo: añadió, por ello, que aquellos vínculos convencionales "responden a altos derechos históricos", como si eso fuera lo importante o, al menos, una fuente de legitimidad que reforzaba el carácter normativo de la obra colonial. Regía una "situación excepcional" que mostraba

con toda evidencia que los ciudadanos españoles tienen de hecho y de derecho limitado allí el uso de los derechos individuales que la ley fundamental del país de origen les otorga, ya que es forzoso adecuarlo a

Este último proceso se había iniciado con decretos como el dictado por el presidente Ricardo Samper el 26 de junio de 1934, que puede verse en la $G M, n^{\circ}$. 179, 28 de junio de 1934, pp. 20132014. Al respecto: Josep Lluís Mateo Dieste y José Luis Villanova, "Les interventores $d u$ protectorat espagnol au Maroc. Contextes de production d'une connaissance politique des cabilas", Cahiers d'Études africaines, vol. LIII (3), $\mathrm{n}^{\circ}$. 211, 2013, pp. 595-624. Disponible en linea: https://doi.org/10.4000/etudesafricaines.17423 (última consulta el 19/02/2020).

86 FAL, Archivo del Comité Nacional de la CNT, carp. 73 A, 2, informe de la Sección Nacional de Coordinación del Secretariado CNT-FAI-JJ.LL. titulado "Acerca de las posibilidades de desarrollo de una acción subversiva en Marruecos y el Sáhara español” y firmado en Barcelona el 19-V1938.

87 "Dahir aprobando y poniendo en vigor el Reglamento que regula el derecho de asociación en la Zona de Protectorado", en Boletín Oficial de la Zona del Protectorado español en Marruecos (Madrid), nº. 4, año XX, 25 de febrero de 1932, pp. 189-194. 
consideraciones de alta politica, cuyo olvido o desconocimiento habria de contrariar gravemente los fines que las naciones signatarias de los Tratados encomendaron al pueblo español.

En consecuencia, la propaganda tendente a abandonar tales obligaciones supremas, "pudiendo ser materia de lícita discusión en el territorio peninsular", penetraba en la esfera penal en África ${ }^{88}$. Se había hecho lo correcto al declarar ilegal la organización comunista y al encarcelar a sus afiliados. En algunos aspectos, el mero hecho de estar en el territorio de la colonia producía una especie de asimilación al estatus jurídico de los "moros" que allí vivían, sin que se dejara por ello de ser ciudadanos españoles, al menos jurídicamente.

El Tribunal Supremo garantizó que el colonialismo prevaleciera sobre el constitucionalismo, para merma de los derechos de los pueblos colonizados pero, también, en menoscabo de los derechos constitucionales del pueblo colonizador. La República no emprendió una tarea de ciudadanización de la población autóctona de las colonias. Es verdad que no existía un consenso acerca de cuál debía ser la política colonial del joven régimen ${ }^{89}$, pero todos los gobernantes republicanos estaban de acuerdo en que la Constitución no era aplicable a las colonias, y orientaron en consecuencia su acción en el seno de la Sociedad de Naciones ${ }^{90}$. Si toleraron la propaganda del nacionalismo marroquí no fue por convicciones constitucionales, sino por impulsos coloniales ${ }^{91}$.

No hay que diluir la concreta acción de la magistratura en el contexto político-cultural. El Tribunal Supremo contribuyó con resoluciones como la estudiada a que el titubeante colonialismo republicano no llegara a fraguar institucionalmente. Lejos de eso, la maquinaria judicial lo impidió bajo variados pretextos, salvando con ello los pilares básicos sobre los que había descansado el colonialismo monárquico. No es casualidad que el Alto Tribunal emplease el argumento nacionalista y colonialista para dictaminar a favor del indulto al general golpista José Sanjurjo. Según la sala 6ª "procedia conservar incólumes los beneficios de carácter vitalicio" que Sanjurjo disfrutaba "por méritos de guerra" derivados de "hechos heroicos realizados en defensa de la Patria". Esa

88 STS 22-IV-1935. Considerando $2^{\circ}$.

89 Por ejemplo, el Partido Socialista Obrero Español (PSOE) se mostró partidario de prolongar la tarea civilizatoria -el colonialismo- en su congreso de 1932, aunque exigía aminorar el peso de los militares y los religiosos. Aunque contemplaba la formación de una élite indigena que fuera asumiendo las riendas del gobierno en el Norte de África, aquella debía ser proclive a la cultura española. FPI, Archivo Aníbal Sánchez Ferrer, carp. 124, exp. 9, p. 12. Sobre el carácter "arrogante" y "paternalista" del discurso republicano en torno a la misión civilizadora: Geoffrey Jensen, "The Peculiarities of 'Spanish Morocco': Imperial Ideology and Economic Development", Mediterranean Historical Review, nº 20 (1), 2005, pp. 81-102, ver p. 91. Sobre el inmovilismo de la República frente a las demandas del nacionalismo marroquí: Paolo La Porte, "Civil-Military Relations in the Spanish Protectorate in Morocco: The Road to the Spanish Civil War, 1912-1936", Armed Forces \& Society, nº 30 (2), 2004, pp. 203-226, ver pp. 221-223. La mejor panorámica histórica sigue siendo la de Gustau Nerín, La guerra que vino de África, Cátedra, Barcelona, 2005, pp. 101-114 y 242-247.

90 Bartolomé Clavero, "Derecho bajo asedio, 1936-1939. República española y Sociedad de Naciones en el escenario europeo entre constitucionalismo y dictadura”, op. cit., pp. 274-278.

91 Así lo reprobaron muchos colonialistas franceses. École Spéciale Militaire, Cours de sociologie musulmane, Imprimerie de l'École Spéciale Militaire, Saint-Cyr, 1935-1936, pp. 59-60. 
referencia velada a las guerras coloniales en Marruecos -cuyos episodios genocidas ya conocemos- integraba nada menos que "los intereses permanentes de la Nación y del Ejército"92. Se confirmaría, entonces, la peor de las sospechas de los radical-socialistas escindidos a finales de 1932: la acción republicana en África estaba desembocando en una forma de "disfrazado imperialismo" 93.

En teoría, el régimen de las plazas de soberanía de Ceuta y Melilla era especial respecto al del conjunto del protectorado y se aproximaba a la normalidad de la metrópoli. La ley de 3 de marzo de 1917 había reformado los arts. 159-161 del código de justicia militar (CJM) acabando con el conocimiento castrense de los asuntos civiles y criminales que alli se ventilaran ${ }^{94}$. Sin embargo, ambas ciudades seguían en las antípodas de la realidad jurídica peninsular. La población indigena mayoritaria, que podía verse envuelta en un proceso ante el juzgado municipal, carecía del derecho a participar en la elección de sus miembros. El nombramiento de jueces y fiscales municipales para el cuatrienio 1931-1935, realizado a partir de las elecciones del 11 de mayo de 1931, no llevó a ningún exponente de la población indigena a la justicia municipal de Melilla, como demuestran las actas de la sala de gobierno de la Audiencia territorial de Granada, a la que pertenecía ${ }^{95}$. El estudio de la Audiencia territorial de Sevilla, a la que se adscribia el juzgado municipal de Ceuta, demuestra que las autoridades judiciales españolas tenían en consideración el parecer clerical cuando se trataba de cotejar la general aprobación social de los candidatos a jueces municipales ${ }^{96}$. Al seguir los consejos de la jerarquía eclesiástica en la provisión de cargos judiciales, la magistratura no sólo premiaba la adhesión a la Iglesia católica, sino que también recompensaba de modo tácito la lejanía respecto al islam. Si lo uno tensaba el mandato constitucional de laicidad, lo otro fomentaba la segregación entre comunidades humanas. Por lo demás, las actitudes racistas presidian la actividad jurisdiccional de los jurados populares, que también juzgaban a los indigenas. El fiscal general de la República lo remarcó en un informe que, a la vista de su enunciación, hace suponer que pesaba más el deseo de criticar la institución popular que el racismo en si97.

92 Comunicación de 25-I-1933 firmada por Mariano Gómez González, presidente de la sala $6^{\mathrm{a}}$. AHN, fondos contemporáneos, Tribunal Supremo, procesos especiales, reservado, exp. 56/1, carp. 7 .

${ }_{93}$ Circular $\mathrm{n}^{\circ}$. 1 con los principales acuerdos del primer Congreso nacional de la Izquierda Radical Socialista (Madrid, 5-XI-1932). ARAH, fondo de Diego Angulo Losada, caja 11-8987, carp. relativa a febrero de 1933.

94 Rafael de Pina, Manual de Derecho procesal penal, Reus, Madrid, 1934, p. 368.

${ }^{95}$ Acta de 3-VI-1931. ARCG, Libro de actas de 1931-1934, sig. 03444, p. 6.

96 Por ejemplo, después de la renuncia de José Jiménez Muro como juez municipal propietario de Ceuta, la sala de gobierno de la Audiencia territorial de Sevilla nombró a Francisco de Caveda y Salcedo, entre otros motivos, porque estimaba probada la existencia de una corriente favorable a él debido a testimonios del alcalde, el general de la circunscripción occidental de Marruecos, el delegado del gobierno de la República y el gobierno eclesiástico del obispado de Ceuta. Véase la sesión de 18-VI-1932. AAPS, Libro de actas de 1930-1935, sig. 193, p. $122 \mathrm{v}^{\circ}$.

$97 \mathrm{El}$ informe de 1933 mostraba como hecho "sistemático" que el jurado declarara "la culpabilidad de todos los acusados, si son moros, y la inculpabilidad, si son españoles". Más adelante, el fiscal de Cádiz destacaba como una de las manifestaciones de las pésimas condiciones de la prisión de Ceuta el hacinamiento confuso de "indígenas y españoles". Oriol Anguera de Sojo, Memoria elevada al Gobierno de la República con motivo de la solemne apertura de 
La excepcionalidad se reflejaba en el ejercicio de la autoridad. Merece la pena destacar el caso de Melilla para mostrar la situación del protectorado marroquí, ya que en dicha ciudad la actividad sindical y el contacto del movimiento obrero con las clases autóctonas fue considerable ${ }^{98}$. Las autoridades republicanas persiguieron duramente a cuantas personas hacian "propaganda entre los moros" relativa a derechos civiles, sociales y politicos. Los delegados del gobierno consideraban peligroso que los trabajadores anarquistas consideraran como sus iguales a los trabajadores indigenas, haciendo campañas de sensibilización y captación entre ellos. Estaba prohibido que los marroquíes militaran en organizaciones obreras, por lo que si bien no figuraban como inscritos en las listas de afiliados de los sindicatos, éstos les extendian papeletas de cotización para disfrutar de los beneficios de la pertenencia. Así lo criticaban las autoridades gubernativas.

De entre los sindicalistas, quienes además divulgaban "la promesa de la independencia de Marruecos" incurrian en una apología del "desprecio a toda clase de autoridades", según los informes internos del servicio de Interior que insinuaban la existencia de un delito no tipificado en ninguna parte. A las organizaciones anarcosindicalistas se las reprimió con dureza en el Norte de África en atención a estas tácticas de criminalización de las movilizaciones de solidaridad obrera e internacionalista. En tanto la autoridad judicial procediera a la "disolución definitiva" de los sindicatos anarquistas en Melilla, el delegado gubernativo acordaba su suspensión temporal; eso ocurrió, por ejemplo, en mayo de 1932. Al mismo tiempo, el delegado proponía al ministro de Gobernación que desterrara a los dirigentes sindicales a la Península en uso de las facultades conferidas por la ley de defensa de la República (LDR) ${ }^{99}$. Para ello le mandó una lista con militantes obreros, a los que consideraba responsables de la "agitación" en la población indigena. Eran "incitadores del acuerdo de organizar la confederación [se refiere a la Confederación Nacional del Trabajo] del Norte de África". Una decena de obreros fueron clasificados según ideología, peligrosidad y cargo orgánico. Se hacía con arreglo a una apreciación material y extrajurídica de orden público, sin sujeción a valores republicanos ni principios constitucionales: de uno de estos obreros fichados se decía que era "sindicalista de mucho cuidado

los tribunales el día 15 de septiembre de 1933 por el Fiscal General de la República, Reus, Madrid, 1933, pp. 9 y 44.

98 Un autor franquista que recibió el Premio Nacional que lucía el nombre del tirano dedicó algunas páginas a destacar la situación crítica de Melilla por este motivo. Tomás García Figueras, Marruecos. La acción de España en el Norte de África, Ediciones Fe, Madrid, 19412, pp. 269-270. En general, la acción del movimiento obrero español en el Norte de África es un aspecto poco estudiado, pero tenemos referencias elementales como las de Eloy Martín Corrales, "Movimiento obrero español y los trabajadores rifeños: entre la complicidad colonial y la solidaridad internacionalista", en AA.VV., Mutations des milieux ruraux dans les montagnes rifaines (Maroc), Groupe de Recherches Géographiques sur le Rif-Université Abdemalek Essaâdi, Tétouan, 2005, pp. 163-178, especialmente pp. 168-176. Próximamente aparecerá un capítulo de libro suscrito por Julián Vadillo Muñoz, "La Kasbah libertaria. El exilio del movimiento libertario español en Argelia (1939-1962)". Aprovecho para agradecer al autor que me haya facilitado su lectura.

99 Sobre esta ley de excepción y su encaje constitucional: Rubén Pérez Trujillano, Creación de Constitución, destrucción de Estado: la defensa extraordinaria de la II República española (19311936), Dykinson, Madrid, 2018, pp. 96-132. Disponible en línea: http://hdl.handle.net/10016/27108 (última consulta el 19/02/2020). 
y comunista de acción"100. El ministro, Santiago Casares Quiroga, celebró el informe y solicitó algunos datos más para obrar en consecuencia a lo pedido101. Los anarquistas del protectorado fueron perseguidos durante todo el lustro republicano, por lo que todo intento de estabilización asociativa fue abortado ${ }^{102}$.

Este tipo de documentación sirve para probar la continuidad esencial entre el colonialismo de la etapa monárquica y el de la republicana, ya se mire al rol asignado al colono o al del colonizado. Al establecerse en el protectorado, los proletarios europeos perdian su estatuto de proletario. A decir verdad, esa desposesión era la única manera de obtener el estatuto de europeo ${ }^{103}$. Pasaban a formar parte de una red difusa de cuadros de la administración colonial, en la que habian de ejercer funciones de control y vigilancia sobre la población autóctona. El fin de este procedimiento no era otro, según ha indicado Foucault, que impedir una coalición entre europeos e indigenas sustentada sobre los lazos de la explotación compartida. Dicha hipótesis era tan aborrecible como la unidad proletaria en la metrópoli ${ }^{104}$.

En consecuencia, los sectores obreros que se zafaban de la ideología racista y se resistían a la separación hostil entre comunidades de sufrimiento, rompian la lógica de la dominación colonial. Este fenómeno resulta visible durante la República en el campo anarcosindicalista, en cuyo seno se intentó constituir una confederación africana que no discriminara entre trabajadores y que no se ciñera a las plazas de soberanía española. Perseverarian en la lucha contra "los distingos de nacionalidad, de fronteras, de razas, de posición social, de injusticia y de desigualdad" años después, ya bajo la bota de la dictadura, cuando los anarquistas españoles exiliados en el Norte de África se mostraron partidarios de la "emancipación universal" y contrarios a todo "nacionalismo estéril"105.

"En nombre de la Libertad, la Igualdad y la Fraternidad, -criticó Félix Tarrago en 1932- en nombre de una civilización y una protección que no existe, se están cometiendo contra nuestros hermanos los árabes, los atropellos más nefandos que se puedan concebir"106. La insinuación de una sociedad de iguales,

100 El informe puede consultarse en: AHN, MG, serie A, leg. 18/2, exp. 12, $n^{\circ} .2$, telegrama $n^{\circ}$. 90 del delegado gubernativo de Melilla al ministro de Gobernación (2-V-1932).

101 Ibid., telegrama $\mathrm{n}^{\circ}$. 15/056 del ministro de Gobernación al delegado gubernativo de Melilla (3-V-1932).

102 Eloy Martín Corrales, "El movimiento obrero en el protectorado español de Marruecos (19311936)", en AA.VV., Ceuta y el Norte de África entre dos dictaduras (1923-1945). XIV Jornadas de Historia de Ceuta, Instituto de Estudios Ceuties, Ceuta, 2013, pp. 177-206, ver pp. 191-192.

103 En la documentación policial, gubernativa y judicial manejada a lo largo de esta investigación, la condición de "europeo" sólo aparece referida a la dominación colonial, como sinónimo de "blanco".

104 La colonización, junto al ejército y la prisión, eran los medios fundamentales para establecer la oposición entre proletariado y "plebe no proletarizada" con base en prevenciones de carácter antisedicioso. Michel Foucault, Microfísica del poder, La Piqueta, Madrid, 1978, edición y traducción de Julia Varela y Fernando Álvarez-Uría, p. 59.

105 "Promesa solemne", en Solidaridad Obrera (Argel), año I, $\mathrm{n}^{\circ}$. 1, 2 $2^{\mathrm{a}}$ quincena septiembre 1944, p. 1. Pueden consultarse éste y los restantes periódicos libertarios que se citarán a continuación en los fondos de la Biblioteca Pública Arús de Barcelona.

106 F. Tarrago, "Sobre organización. Por la Regional Africana”, en Solidaridad Proletaria (Sevilla), 7 de mayo de 1932 . 
más que suponer una realización del programa constitucional aprobado en 1931, implicaba un contundente intento de superación del régimen anterior y, en ese sentido, una aspiración a intervenir sobre el régimen constitucional en ciernes. Parafraseando a los anarcosindicalistas de Melilla, era preciso dejar atrás "la triste época de Martínez Anido" ${ }^{107}$. La persecución de este anhelo era precisamente lo que convertía a estos obreros en criminales a ojos de las autoridades. La negación de la ciudadanía a los pueblos colonizados, por lo tanto, tenía efectos restrictivos de la ciudadanía del pueblo español constitucionalmente reconocido, sobre los cuales pivotaba. Las autoridades gubernativas auspiciaron el esquirolaje armado para contrarrestar la influencia de las movilizaciones huelguísticas, lo que llevó a ciertos episodios de violencia ${ }^{108}$. El estigma de "extremista" conocia variantes agravadas en el territorio de las colonias, sobre todo cuando aquellos a quienes se etiquetaba como tales se atrevían a imaginar una República sin colonias. Así lo sufrieron los sostenedores de Izquierda Republicana y Anti-imperialista (IRYA), un partido comunista que concurrió a las elecciones constituyentes de 1931 con la promesa de reconocer "la autonomía del Riff y su incorporación a la República Federal Española"109. La difusión de ideas favorables a la autodeterminación de las colonias se persiguió conforme al delito de excitación a la rebelión o a la sedición ${ }^{110}$.

Como muestra nítida de la negación de igualdad de derechos ante la administración colonial, el régimen judicial se hallaba separado según la nacionalidad de los ajusticiados. Súbditos todos de un mismo Estado, el español, poseían niveles desiguales de tutela judicial de los derechos, lo que se derivaba de -y a la vez modulaba- una titularidad desigual de los mismos. En la zona de Tánger funcionaba un Tribunal mixto desde 1924 integrado por magistrados ingleses, franceses y españoles. Los fiscales eran franceses y españoles. Sus competencias consistian en juzgar a los súbditos de las naciones que antes del régimen de protectorado disfrutaban alli del de capitulaciones o jurisdicción consular, para lo que se llegaron a aprobar algunos códigos ad hoc ${ }^{11}$.

La población indigena que trasgredía el ordenamiento jurídico en suelo africano estaba sometida a otros caminos judiciales: 1) por el fuero castrense en caso de delitos que afectasen a la autoridad colonial o a la población de origen

107 "Los matones de la UGT. El cobarde crimen realizado en Melilla", en Solidaridad Proletaria (Sevilla), 7 de mayo de 1932 .

108 Así lo declaraba el texto citado, que aprovechaba para arremeter contra los rivales sindicales de la Unión General de Trabajadores. Ibid.

109 AHTMTS, fondo República, leg. 239, nº. 2209, causa nº. 28/1931, p. 420.

110 Por ejemplo, propaganda del Partido Comunista de España: STS 10-IX-1934.

111 Santiago Sentís Melendo, Derecho procesal civil, criminal y organización judicial, Reus, Madrid, 1934, pp. 174-175. Rafael de Pina, Manual de Derecho procesal penal, op. cit., pp. 369372. Sobre el régimen judicial de Tánger, los escuálidos “derechos adquiridos" por nacionales -no por indígenas- y la política continuista de la República -que renovó el estatuto en 1935 sin ninguna sensibilidad constitucional-: Ministère des Affaires Étrangeres, La question de Tanger, Imprimerie Nationale, Paris, 1945, pp. 25-27 y 33-34. Una exposición de dichos códigos (penal, de obligaciones y contratos y de comercio) y de la réplica administrativa de la planta judicial peninsular (con sus particularidades) en: Francisco de P. Rives Martí, Derecho judicial español en la Zona de nuestro Protectorado en Marruecos, Reus, Madrid, 1921, pp. 13-37. 
metropolitano ${ }^{112}$, o 2) por sus propios tribunales, ya fueran los de derecho islámico (justicia xeránica o cheránica) o de derecho territorial (justicia majzení o majseniana). La represión judicial de la población indígena, tanto en el ámbito común como en el especial, merece ser abordada en un tercer punto, en donde intentaré aislar 3) de qué manera la persistencia de un sistema de dominación colonial desencadenaba un dispositivo en el devenir constitucional de la República que engullía a españoles y marroquies. A grandes rasgos, puede anticiparse que el régimen republicano mantuvo esencialmente intacta la estructura judicial heredada de la monarquia borbónica, con sus consecuentes secuelas segregativas. Las autoridades españolas procuraban intervenir en todos los ámbitos sujetos a la autoridad indigena "sin que los administrados se enteren", ya fuera convenciendo u obligando ${ }^{113}$.

\subsection{Jurisdicción militar}

En el primer plano, las contiendas jurisdiccionales eran decididas por el consejo de ministros cuando surgian dudas sobre la competencia en torno al conocimiento de determinado problema por la jurisdicción ordinaria o la militar, tal y como venía siendo desde 1915114. El decreto de 17 de junio de 1931 es altamente expresivo para estudiar la reforma de la justicia militar emprendida por la República. Para la Zona española del Protectorado de Marruecos significaba una completa continuidad del régimen de excepcionalidad conocido hasta entonces: los efectos del decreto de 11 de mayo, tendente a reducir la jurisdicción castrense, no resultaban aplicables a la colonia ${ }^{115}$. Pero también se colige una conclusión interesante para la metrópoli. La distorsión jurisprudencial del decreto de mayo significó la ampliación a suelo peninsular del régimen de excepción colonial.

El Tribunal Supremo tuvo ocasión de revisar este régimen, es decir, tuvo oportunidad de estudiar los efectos de la entrada en vigor de una Constitución democrática sobre el sistema judicial. Sin embargo, rehusó reconocerle eficacia alguna en suelo africano, ni a favor de la población indigena ni en pro de la española. En sentencias como la del 7 de marzo de 1933, el Alto Tribunal determinó que la jurisdicción ordinaria establecida por el art. 322 de la ley provisional orgánica del poder judicial (LOPJ) y el art. 16.2 CJM tenía carácter preferente solamente en el supuesto de personas sujetas a la jurisdicción ordinaria u otras aforadas -como los militares-, lo que excluía aquellos casos en los que víctima o procesado carecian de la nacionalidad española o cualquiera otra europea, así como del estatus de protegido por España. Seguía rigiendo el

112 A semejanza de la politica judicial de Francia en Argelia. Cándido Lobera, El Gobierno de las Kabilas, s/e, s/1, 1911, p. 89.

113 Coronel Capaz, comandante Galera y capitán Ochoa Iglesias, Asuntos indigenas, op. cit., pp. $17-18$.

114 La real orden del Ministerio de Gracia y Justicia de 16-IV-1915 determinó que la resolución de tales asuntos correspondería al ejecutivo debido a la inexistencia de una legislación especial del protectorado sobre el particular. Francisco de P. Rives Martí, Derecho judicial español, op. cit., p. 70 .

115 Rafael de Pina, Manual de Derecho procesal penal, op. cit., p. 307. Faustino Menéndez-Pidal, Derecho judicial español (Organización de los tribunales), Reus, Madrid, 1935, p. 16. 
art. 6 del dahir de 1 de junio de 1914, en el sentido de que la jurisdicción española en zona marroquí poseía un carácter eminentemente excepcional. Sin derechos justiciables en foros coherentes con derechos y no sólo con autoridades, el ordenamiento constitucional perdia eficacia. Significativamente, la sentencia mencionada se limitaba a negar la atracción de la jurisdicción española ordinaria al tiempo que se abstenía de hacer declaración sobre cuál sería la jurisdicción competente -la militar o la majseniana-, lo que suponía un reconocimiento paladino de la independencia reconocida a dichas esferas jurisdiccionales ${ }^{116}$.

En cuanto a los españoles, sentencias como la de 28 de abril de 1933 confirmaron que el sistema punitivo de los españoles en Marruecos seguiría siendo el del código penal de la Zona del Protectorado en Marruecos (CPM) aprobado en 1914, con independencia de la entrada en vigor del CP de 1932 para la metrópoli117. Sí que confirió el nuevo código una dimensión singular a las agravantes por nocturnidad, despoblado y cuadrilla ${ }^{118}$. Los derechos reconocidos en el ordenamiento jurídico estatal debían ser expresamente extrapolados a la Zona del Protectorado de Marruecos mediante dahir. El Tribunal Supremo confirmó este mecanismo de integración de los derechos laborales en tierras africanas basada en una lógica de excepcionalidad, con lo que una de las perlas del republicanismo desconoció lo que sucedia al otro lado del Estrecho de Gibraltar ${ }^{119}$. En última instancia, que el dahir de 1914 siguiera intacto quiere decir que lo estaba por entero el convenio hispano-francés de 1912120. El alejamiento de la población autóctona del proceso de ciudadanización quedó confirmado desde el principio del régimen republicano.

\section{2. Jurisdicciones indigenas}

En el segundo plano, o sea, en el de la jurisdicción indígena, sólo durante el segundo bienio se realizaron algunas modificaciones leves al respecto, a través del reglamento para la organización de los tribunales de justicia majsenianos en la Zona de Protectorado de España en Marruecos ${ }^{121}$. La intervención de la autoridad española en la justicia religiosa era posible teóricamente, según establecía el decreto regulador del protectorado (art. 7), pero escasa y

116 STS 7-III-1933.

117 Por delito de estupro: STS 28-IV-1933. En este caso particular la importancia no sería menor, pues implicaba someterse a la regulación del delito de estupro aparecida en el art. 344.3 del CP de la Zona del Protectorado, idéntico al derogado art. 458.3 CP de 1870 y carente de los elementos del nuevo tipo según lo había alterado el art. 439 del CP de 1932. Subrayó el hecho Félix Álvarez Valdés, "Jurisprudencia del Tribunal Supremo. Criminal”, Revista de Derecho Público, $\mathrm{n}^{\circ}$. 18, 15 de junio de 1933, pp. 181-185, ver pp. 183-184.

118 Alfonso Rodríguez Dranguet, Defensa social. Tratamiento de los peligrosos. Legislación de vagos y maleantes. Ley y reglamento, Góngora, Madrid, 1935, pp. 86-87.

119 SSTS 31-V-1933, 3-VI-1933, 5-VI-1933 y 30-X-1933. Enrique Zarandieta, Las leyes sociales interpretadas por el Tribunal Supremo, Reus, Madrid, 1934, prólogo de Juan Bautista Guerra, p. 87.

120 Rafael de Pina, Manual de Derecho procesal penal, op. cit., p. 368.

121 Alta Comisaría de España en Marruecos-Delegación de Asuntos Indigenas, Reglamento para la organización de los Tribunales de Justicia Majsenianos en la Zona de Protectorado de España en Marruecos. Dahir de 8 de Dul-Kaada de 1353 (correspondiente al 12 de febrero de 1935), Imprenta El-Mahdia, Tetuán, 1935. Se trata de una edición bilingüe en castellano y árabe. 
desaconsejada en la práctica desde hacía años ${ }^{122}$. En el resto de esferas jurisdiccionales, la intervención era significativa incluso con carácter previo a las actuaciones judiciales de las autoridades indigenas, llegando a trazar un importante panorama de justicia gubernativa ${ }^{123}$. En cualquier caso, la intervención española no sólo controlaba la aparición de actitudes y comportamientos anticolonialistas, sino que buscaba que la justicia autóctona ejerciera un rol funcional a la empresa colonial. Por ello, la configuración de un entramado de justicia mediatizada servía para aprovechar las instituciones y prácticas indígenas para la sujeción de los pueblos originarios por medios a los que la administración colonial no podia acudir ${ }^{124}$.

Un decreto de 1935 atribuyó la competencia sobre las materias de índole criminal, civil y comercial, "siempre que ambas partes sean súbditos marroquíes, no protegidos de potencias extranjeras" (art. 3), a una estructura de tribunales integrada por tres escalones. En la primera instancia se hallaban los tribunales de Bajaes en las ciudades y de Kailes en las kabilas. Le seguían los tribunales de apelación y, en la cúspide, se situaba el Tribunal Superior de Justicia Majseniana, presidido por el gran visir (arts. 1-2). Éste ostentaba la categoría de ministro del Interior del jalifa Muley el Hassan Ben-el-Mehdi Ben Ismail, por lo que carece de sentido siquiera imaginar un esbozo de separación de funciones, máxime si se tiene en cuenta que la ejecución de los fallos se encomendaba a las autoridades gubernativas locales conforme al derecho consuetudinario del lugar (art. 25).

Además, la disposición general $1^{\mathrm{a}}$ consagraba el principio de primacía de la jurisdicción xeránica, de manera que el litigio podia ser suspendido y pasar automáticamente a conocimiento de un tribunal del orden islámico a iniciativa de parte en cualquier fase del proceso. Esta cláusula confería carácter excepcional a la justicia secular marroquí respecto a la específicamente musulmana, lo que significa que la República abrazó un principio de no injerencia en la jurisdicción islámica, a diferencia de lo que hacía Francia tanto en Marruecos -donde regía un

122 Debía suministrarse una "vigilancia discreta" combinada con el respeto máximo a la independencia judicial del kadi, y el interventor debía proteger dicha independencia frente a las posibles injerencias del kaid, o sea, de la autoridad indigena en la esfera gubernativa. Coronel Capaz, comandante Galera y capitán Ochoa Iglesias, Asuntos indigenas, op. cit., pp. 21-22 y 2830 .

123 Francisco Sayáns Gómez, Etnografías en el protectorado español de Marruecos: una revisión de la labor antropológica de la intervención militar, tesis doctoral, Universidad Autónoma de Madrid, Madrid, 2015, p. 475. Disponible en linea: http://hdl.handle.net/10486/669722 (última consulta el 19/02/2020). Consúltese también el trabajo de Mateo Dieste, que documenta numerosos casos de injerencia española en el juicio de delitos comunes y políticos durante la etapa 1931-1936: Josep Lluís Mateo Dieste, “El interventor y el caíd. La politica colonial española frente a la justicia marroqui durante el Protectorado de Marruecos (1912-1956)", Hispania, n ${ }^{\circ}$. LXVII (226), 2007, pp. 643-670, por ejemplo pp. 651, 653, 655-657 y 663-664. Disponible en linea: https://doi.org/10.3989/hispania.2007.v67.i226.56 (última consulta el 19/02/2020). Sobre el mismo tema, aunque basado en fuentes secundarias y en la manualística colonial española: Sergio Carro Martín, "El proceso judicial musulmán durante el Protectorado español de Marruecos: algunas observaciones coloniales", Anaquel de Estudios Árabes, nº. 30, 2019, pp. 61-84. Disponible en linea: https://doi.org/10.5209/ANQE.57058 (última consulta el 19/02/2020).

124 Era una "táctica de gobernabilidad colonial" bastante común. Para su uso británico en India y con fines "modernizadores": Mark Brown, Penal Power and Colonial Rule, Routledge, New York, 2014, pp. 169-174. 
sistema de asociación similar al español- como en Argelia -paradigma del asimilacionismo ${ }^{125}$. Al mismo tiempo, la elección no hacía sino asumir intacta una costumbre, consistente en trasladar el litigio del kaid al kadi cuando, al conocer en materia gubernativa y penal (también de manera parcial en asuntos civiles y comerciales), una de las partes invocara la fórmula "apelo a Dios y a la justicia del Profeta"126. En este sentido, el panorama judicial del Marruecos sometido a la dominación española presentaba un perfil próximo a la unidad jurisdiccional -de tipo religioso-, sobre todo si se compara una vez más con el modelo francés ${ }^{127}$.

Ahora bien, la afirmación ha de ser matizada, ya que el ministro de Justicia se reservaba ciertas potestades de control sobre las aptitudes morales de parte del personal de los kadidatos de la zona jalifiana: los adul128. Por más que la jurisdicción xeránica gozara de gran autonomía respecto a las autoridades metropolitanas -como demuestra el proceso de revisión de la actividad de los mufties por parte de una comisión de ulemas sin aparente injerencia española ${ }^{129}$

125 La primacía del derecho islámico y sus tribunales marca un claro contraste entre el protectorado español y el francés. Lo han subrayado numerosos estudios. Entre otros: Manuel Feria, "Conflictos de legitimidad juridica en Marruecos: el impacto del Protectorado", en Fernando Rodríguez Mediano y Helena de Felipe Rodríguez (coords.), El Protectorado español en Marruecos: gestión colonial e identidades, Consejo Superior de Investigaciones Científicas, Madrid, 2002, pp. 37-62, especialmente pp. 53-54, y Josep Lluís Mateo Dieste, "El interventor y el caid”, op. cit., p. 648. Yolanda Aixelà-Cabré, "Imazighen y árabes del Protectorado español. Una revisión de la construcción nacional del Marruecos contemporáneo", en Yolanda Aixelà Cabré (ed.), Tras las huellas del colonialismo español en Marruecos y Guinea ecuatorial, Consejo Superior de Investigaciones Cientificas, Madrid, 2015, pp. 21-59, concretamente pp. 25 y 32-33. La administración colonial francesa quiso evitar en Marruecos los errores cometidos en Argelia a raíz de la "excesiva islamización de las kabilas" y los problemas que eso generaba en la población bereber. Por ello, apostó por un sistema de gobierno indirecto basado en la idea de asociación, en el que además no se confería especial alcance a la jurisdicción islámica. Asi lo ha explicado Patricia M. E. Lorcin, Imperial Identities. Stereotyping, Prejudice and Race in Colonial Algeria, I. B. Tauris, New York, 1995, pp. 171-173 y 227-228. Por lo demás, la política francesa de asimilación judicial también menguó en otras colonias, como por ejemplo en Senegal. La jurisprudencia fue abriendo camino a la jurisdicción musulmana entre 1912 y 1932, hasta que este último año se decretó la competencia exclusiva de los tribunales islámicos en lo tocante al estatus personal de la población originaria cuya confesión fuera la musulmana. Dominique Sarr y Richard Roberts, "The Jurisdiction of Muslim Tribunals in Colonial Senegal, 1857-1932", en Kristin Mann y Richard Roberts (eds.), Law in Colonial Africa, Heinemann, Portsmouth, 1991, pp. 131-141.

126 Por tanto, la justicia ejercida por el kadi pasaba a convertirse en una suerte de arreglo judicial de primera instancia, y la justicia xeránica un nivel de apelación bastante frecuente. Coronel Capaz, comandante Galera y capitán Ochoa Iglesias, Asuntos indigenas, op. cit., pp. 22 y 31-33.

127 Un análisis de este aspecto, considerado negativo, en: "La justice indigène au Maroc", artículo de L'Europe Nouvelle (París, 25-VIII-1934) conservado en ABNE, sig. AFRGFC/382/5.

128 El kadí regional proponía al ministro del personal análogo a los auxiliares de justicia y con ciertas potestades semejantes a la de instrucción del expediente (los llamados adul), pero correspondía al titular de Justicia la decisión última en atención al examen de "buena conducta y moralidad". Véase el dahir reglamentando la función de los adul, de 7 de Rayeb de 1354 (31 de octubre de 1935) en: Alta Comisaria de España en Marruecos-Delegación de Asuntos Indigenas, Cheráa, Tip. Casa Gomáriz, s/1, 1936, pp. 9-11. Sobre el adul: Cándido Lobera, El Gobierno de las Kabilas, op. cit., pp. 93-94.

129 Decreto visirial ordenando se constituya la Comisión de exámenes de los mufties, 29 de Xual de 1353 (4 de febrero de 1935). Alta Comisaria de España en Marruecos-Delegación de Asuntos Indígenas, Cheráa, op. cit., pp. 23-24. 
aquella suponía una vía de intervención estatal en un asunto tan relevante para la colonización como las enajenaciones de inmuebles, las cuales eran realizadas con arreglo a la ley musulmana por el kadi y el adul130. La intervención por vía tangencial no ha de ser vista tanto como un comedimiento metropolitano y un gesto de confianza en las instituciones indigenas sino como un efecto derivado de la carencia de funcionarios especializados en derecho musulmán ${ }^{131}$. La intervención metropolitana en la unidad jurisdiccional del protectorado respondia a intereses económicos, puramente coloniales $\mathrm{y}$, en modo alguno, a reglas constitucionales o valores republicanos.

Además, el criterio de delimitación competencial era deudor de un principio de discriminación en detrimento de las kabilas bereberes, ya que mientras que los tribunales de Bajaes podian conocer de causas criminales cuando la pena no excediera de cinco años de cárcel o de materia civil y mercantil cuando el monto de la demanda no superara las 10.000 pesetas, el límite máximo para los tribunales de Kaides descendía a dos años de cárcel y 1.000 pesetas de cuantía (art. 3). A partir de dichos máximos eran competentes en primera instancia los tribunales de apelación, que en verdad eran órganos unipersonales nombrados por la autoridad gubernativa indígena (arts. 2 y 6). Así las cosas, las autoridades españolas respetaron cierto principio de desconfianza xenófoba existente en las autoridades indigenas de base, a las que reconocieron un alto grado de discrecionalidad: la asignación de penas a los distintos delitos y la subordinación a aquel criterio del reparto de competencias no disponía de reglas fijas y conocidas $^{132}$. Por otro lado, las autoridades españolas prefirieron reforzar la autoridad teocrática del sultán y su gobierno antes que la autoridad cuasi democrática de las kabilas, cuya subdivisión en dáchara presentaba cierta semejanza con el jurado ${ }^{133}$. Los kadies de kabilas carecian de funciones relacionadas con el derecho de propiedad sobre bienes inmuebles que no

130 Como había dicho un influyente colonialista "[c]olonizar es atraer á un país nuevos habitantes y fijarlos sobre el suelo; y nada fija verdaderamente como la propiedad". Cándido Lobera, El Gobierno de las Kabilas, op. cit., pp. 98 y 102.

${ }^{131}$ Reconoció este punto Constante Miquélez de Mendiluce, La justicia en Marruecos. El Cádi, el Caid y la yemáa bereber, s/e, s/1, 1930, p. 2.

132 No ocurriría hasta avanzado el régimen dictatorial de Franco, cuando se entró a definir tipos de delitos (dolosos y culposos), grados de infracción penal (consumación, tentativa, proposición, conspiración y provocación), circunstancias modificativas de la responsabilidad, etc.: Cesáreo Rodríguez-Aguilera, Leyes de bases para la reforma de la justicia majzeniana de la Zona española de Protectorado en Marruecos, s/e, Barcelona, 1954, pp. 12-14. Ejemplar mecanografiado conservado en ABNE, sig. AFR 14459.

${ }^{133}$ La yemáa de dáchara era un órgano asambleario de gobierno y justicia que decidía y obraba en materia criminal, civil, politica y financiera con soberania. Cada kabila estaba compuesta por varias dáchara. El caid, como una suerte de gobernador indígena dependiente del sultán, respetaba su ámbito de soberanía. Por esto, las instituciones rifeñas fueron consideradas por algunos observadores como "democráticas por excelencia”. Cándido Lobera, El Gobierno de las Kabilas, op. cit., p. 79. Otros, por el contrario, fueron más críticos: "no es ni demócrata ni libertaria", sino "tradicionalista" y vinculada al principio patriarcal. Su libertad y soberanía era puramente "aparente", pues en su epicentro estaba "el recelo de sumisión a una autoridad o un régimen de gobierno que sojuzgara sus más viejas tradiciones". Coronel Capaz, comandante Galera y capitán Ochoa Iglesias, Asuntos indigenas, op. cit., pp. 10-11. En cualquier caso, eran instituciones adversas a la soberania plena del sultán. 
estuvieran inscritos en el Registro de inmuebles de la Zona de Protectorado ${ }^{134}$. El primado de la estabilidad de la empresa colonial en la región llevó a los gobiernos a la abjuración de todo principio constitucional republicano (igualdad, laicidad, democracia, etc.).

Ciñéndonos al proceso penal, cabe decir sin ambages que el mínimo de reglas jurídico-positivas establecidas por el reglamento no aseguraban ninguno de los derechos de seguridad personal preconizados por la Constitución española. Así vista, la desconexión entre el ordenamiento constitucional español y el ordenamiento jurídico-penal hispano-marroquí era absoluta como, por otra parte, venía siendo desde el comienzo del régimen de protectorado dos décadas atrás ${ }^{135}$. El conjunto de medios de defensa de que disponía el acusado prácticamente se reducia al derecho a ser oído ante el órgano judicial. Sin embargo, no existía nada que se pareciera al habeas corpus: se exigía que el interrogatorio del acusado tuviera lugar dentro del plazo de setenta y dos horas desde su detención, sin que esto debiera hacerse ante la autoridad judicial competente (art. 10). Tampoco habia un mínimo de igualdad ante los aplicadores del derecho, pues se permitía la libertad provisional del acusado previo pago de fianza sin que se especificara de ninguna manera algún criterio para la determinación de los montantes dinerarios (art. 11). Quizá en previsión de una evasión generalizada de la acción de la justicia majseniana -para acabar en la xeránica-, el reglamento admitía la posibilidad de una condena en situación de rebeldía (arts. 11, 24 y 27). En fin, la interposición de recurso de apelación desplegaba efectos suspensivos de la sentencia, pero esto era contrapesado mediante el reconocimiento de la potestad discrecional de imponer "castigos de privación de libertad" cuando los tribunales probasen la mala fe del apelante, sin que ello tuviera por qué ocurrir mediante un proceso penal (arts. 29 y 30).

A mi parecer, la ausencia de una norma de derecho penal sustantivo que concretase las penas, el mantenimiento del poder sultánico sobre los tribunales conocedores de materias con cierta enjundia y la escasez de reglas procesales lastraban poderosamente la reforma judicial del período republicano. En el fondo, la justicia seguía dependiendo en exceso tanto de la equidad como del caid, bajá o gobernador, por lo que pueden acentuarse dos conclusiones: primero, el impacto del régimen constitucional sobre la población "protegida" fue mínimo, al prevalecer la justicia de tipo gubernativo y el control gubernativo sobre la justicia majseniana ${ }^{136}$. Y segundo: pese a la supremacía de la jurisdicción específicamente religiosa -la xeránica- sobre la secular, las autoridades españolas rehusaron cuestionar la unidad interna del Imperio jerifiano, dando al traste con las aspiraciones bereberes y en particular rifeñas no sólo de secesión política sino de mero reconocimiento de sus órganos de justicia privativos y regidos por su propio

134 Dahir dictando normas para la organización de los Kadidatos en esta Zona de Protectorado, 18 de Ramadán de 1353 (26 de diciembre de 1934). Alta Comisaría de España en MarruecosDelegación de Asuntos Indígenas, Cheráa, op. cit., pp. 3-4. Sobre los registros hispanomarroquies, bajo control de las autoridades españolas: Francisco de P. Rives Martí, Derecho judicial español, op. cit., pp. 13 y 144-152.

135 Francisco Sayáns Gómez, Etnografías en el protectorado español de Marruecos, op. cit., pp. 490-491 y 503.

136 Subsistian, entonces, los rasgos que Mendiluce habia apreciado en la justicia del caid. Constante Miquélez de Mendiluce, La justicia en Marruecos, op. cit., p. 3. 
derecho consuetudinario ${ }^{137}$. Ambos hechos suponian una continuidad en la política española de respeto a las relaciones de dominación local y, a la larga, supondria un elemento de reforzamiento favorable a la soberanía unitaria e indivisible del sultán y al proceso de construcción nacional marroquí en torno a su autoridad, excluyendo toda pluralidad interna o concéntrica ${ }^{138}$. Si se tiene en cuenta que administrar justicia era entendido como el "primer deber de la soberanía"139, dar peso directo al sultán en la justicia secular e indirecto en la teológica -por su naturaleza de descendiente de Mahoma- acarreaba nutrir la soberanía de aquel.

\subsection{Africanismo, justicia y Constitución}

El art. 159 CJM mantenía en perpetuo estado de guerra al protectorado español en el Norte de África. Durante la Restauración, la jurisdicción castrense era la general y permanente en todas las plazas de África. Como dijo un jurista militar, los consejos de guerra conocian "hasta de las causas por adulterio" 140 . Los cambios operados por la República fueron bastante tímidos, pudiéndose afirmar rotundamente que la jurisdicción castrense conocía hasta de los desahucios. En este aspecto, carece de sentido distinguir entre bienios ${ }^{141}$, lo que confirma que estamos ante un envés sombrio de la institucionalidad republicana más que ante una tensión interna a la misma. Después de que el decreto de 11 de mayo de 1931 redujese la jurisdicción de los tribunales de Guerra y Marina, una orden de 17 de junio determinó que dicha norma no era aplicable a la Zona

137 En esto se diferenciaba claramente la pauta seguida por España en relación a la de Francia para su zona marroquí. Subrayaba la peculiaridad, por lo demás conservada por la dictadura franquista, Cesáreo Rodríguez-Aguilera, Leyes de bases para la reforma de la justicia majzeniana, op. cit., p. 3. Francia siguió en Marruecos la táctica de apoyar a los pueblos bereberes para hacer frente a los árabes -incluso con doctrinas supremacistas-, aunque sin mucho éxito. Jacques Berque, French North Africa. The Maghrib between Two World Wars, Faber and Faber, London, 1967, pp. 293-301. Robin Bidwell, Morocco under Colonial Rule. French Administration of Tribal Areas 1912-1956, Cass, New York, 2012, pp. 50-57 y 60-61.

138 No estoy de acuerdo con Aixelà, quien sostiene todo lo contrario. Las autoridades españolas no distinguian entre comunidades árabes y amazigh, lo cual, unido a las dificultades para afrontar la diversidad cultural, habría animado a las autoridades españolas -ya según la referida autora- a adoptar politicas permisivas para ambos grupos. Por lo demás, su estudio sobre los planos discursivos y prácticos del colonialismo español en Marruecos y Guinea es altamente recomendable. Yolanda Aixelà-Cabré, "Exploring Euro-African pasts through an analysis of Spanish colonial practices in Africa", Canadian Journal of African Studies / Revue canadienne des études africaines, $\mathrm{n}^{\circ}$. 51, 2017, pp. 23-42, ver p. 32. La autora sostiene la misma idea en "Imazighen y árabes del Protectorado español. Una revisión de la construcción nacional del Marruecos contemporáneo", op. cit., pp. 34 y 54.

139 Francisco de P. Rives Martí, Derecho judicial español, op. cit., p. 90.

140 Ángel Salcedo y Ruiz, Substantividad y fundamento del Derecho militar, Real Academia de Ciencias Morales y Políticas, Madrid, 1913, p. 60.

141 Pongamos un caso. La sala de gobierno de la Audiencia territorial de Sevilla trató la petición dirigida por un arrendatario al ministro de Justicia en el sentido de que la jurisdicción de Guerra se abstuviera de ejecutar una sentencia de desahucio que aquella misma había dictado después de requerir de inhibición al Juzgado municipal de Ceuta. El Ministerio de Guerra ordenó tal reclamación jurisdiccional. El juez municipal dictó resolución inhibitoria. La Audiencia territorial, el Ministerio fiscal y, antes, el juez de primera instancia de Ceuta en su dictamen, se ampararon en la firmeza del auto de inhibición para confirmar la jurisdicción militar. Sesión de 4-III-1933. AAPS, Libro de actas 1933-1934, sig. 182, pp. 11-11 vo. 
española de Protectorado en Marruecos. Este condicionamiento jurídiconormativo propició dos procesos de gran relevancia histórica: de un lado, la ascensión en la carrera militar de los militares que servían en aquel territorio y, por otro, el control militar de la población civil, aborigen o no, con un carácter casi total. Desde otra perspectiva, dicho condicionamiento impulsaba la asunción de competencias de ámbito administrativo civil por parte del ejército, y la normalizaba.

El señorío militar sobre Marruecos incidió sobre la implantación y el desarrollo del constitucionalismo republicano hacia fuera y hacia dentro. En la jurisdicción castrense, el racismo institucionalizado se multiplicaba y se dejaba ver con mayor claridad. El tratamiento deshumanizador del "indígena" o el "moro" quedaba de relieve no sólo por la utilización de semejantes categorias racistas, sino por la asignación de números naturales a los marroquíes que prestaban el servicio militar, a diferencia de lo que ocurría con los militares españoles. Mientras que a los primeros se les denominaba "número 12.342", "askari" o "soldado 12.342" (o su grado: "cabo $n^{\circ} .2 .903$ "), en ocasiones incluso sin poner a continuación el nombre, a los segundos se les llamaba por su nombre completo, aparte de la graduación militar ${ }^{142}$. En cuanto al peso de los relatos en el marco de un proceso, el de los soldados blancos predominaba sobre el de los indigenas, para lo cual podian darse por válidas suposiciones y prejuicios basados en un presunto conocimiento de las "costumbres de los indígenas" alegado por el interesado según le conviniera ${ }^{143}$.

A la población civil autóctona se la clasificaba conforme al mismo patrón. Como muestra de que el calificativo de "indigena" era tan despectivo como el de "moro" o "mora", cabe apreciar el uso indistinto y sinonímico de ambos conceptos. Así lo hacian los tribunales para describir tanto a los sujetos activos como a los sujetos pasivos de los delitos, lo que da pistas sobre el impacto de la categoría en la determinación de la penalidad según su presencia en el victimario y en la víctima ${ }^{144}$. En el orden castrense, en un caso de 1932 , a la víctima de una agresión machista se la etiquetó insistentemente como "la mora" tanto por los autos judiciales como por el hospital de la Cruz Roja ${ }^{145}$, y a los testigos del asesinato de un soldado marroquí y los conocedores de algunas de sus circunstancias se les denominaba "indigenas" o "moros" antes que cualquier otra

142 Cotéjese el uso del léxico por parte de fiscales y jueces militares en un caso especialmente llamativo, porque se trata de una reyerta entre soldados marroquies con cierto racismo de fondo (un borracho agredió con la porra al "negro de la banda" o "negro de la nuba", a su vez embriagado, porque le molestaba). AHTMTS, fondo de Personal indigena, leg. 49, $\mathrm{n}^{\circ}$. 17 , causa $\mathrm{n}^{\circ}$. 2749/1931, pp. 67-69 y 82-83 vº La sentencia del consejo de guerra, de 16-IV-1932, también comparte este lenguaje: pp. $84-84 \mathrm{v}^{\mathrm{o}}$.

143 Decreto del juez instructor emitido en Nador, 31-VIII-1932. AHTMTS, fondo de Personal indígena, leg. $50, \mathrm{n}^{\circ} .8$, causa $\mathrm{n}^{\circ} .752 / 1932$, pp. 34-35.

${ }_{144}$ En el caso de daños y lesiones cometidas por un "moro", parece que los tribunales otorgaban relevancia al hecho de que la víctima fuera una "mora" en lugar de una europea. Sentencia de la Audiencia provincial de Cádiz nº 11 (17-I-1936), por delito de daños. AHPCad, Penal, Sección $1^{\text {a }}$, Libro de sentencias de 1936, sig. 4229.

145 AHTMTS, fondo de Personal indígena, leg. 50, $\mathrm{n}^{\circ}$ 10, pieza de embargo instruida para asegurar las responsabilidades civiles dimanantes de la causa ${ }^{\circ}$. 584/1932, pp. 43, 44, 47 y 49. 
$\operatorname{cosa}^{146}$. Por lo demás, este lenguaje racista formaba parte del bagaje institucional en todos los órdenes ${ }^{147}$.

La inferiorización de la población autóctona del Norte de África se plasmaba en dos tendencias interpretativas principales. Es tal su solidez que cabe apreciarla en la administración colonial y en la peninsular, en la justicia y en la gobernación, en la esfera civil y en la militar. Una primera manifestación de la devaluación cultural, moral y, en definitiva, antropológica de la población africana, tenía un carácter bastante evidente. A la presunta bajeza de la condición moral e intelectual de esta población, mayoritaria en las zonas del Protectorado, le seguía un doble tratamiento. Operaba un principio de presunción de culpabilidad en relación a la comisión no ya de delitos de bagatela sino, también, de delitos graves de sangre.

Por lo que toca a los delitos leves, las audiencias provinciales de la Peninsula manifestaban una tendencia a castigar con severidad los hurtos y robos cometidos por la población aborigen del Norte de África. Los "moros" -así eran referidos- eran objeto de una penalidad mayor y dificilmente merecian la apreciación de circunstancias atenuantes a menos que éstas estuvieran marcadas por el factor paternalista. Al contrario, además de etiquetárseles generalmente como sujetos de "mala conducta", los tribunales solían aplicar con amplitud las circunstancias agravantes que tenían más a mano, como la reincidencia ${ }^{148}$. En este sentido, no es raro encontrar supuestos de apabullante desproporcionalidad entre la infracción perseguida y el castigo impuesto de iure o de facto. Por ejemplo, la Audiencia provincial de Barcelona absolvió en 1932 a un natural de Tánger al que se acusaba de robo frustrado en una estación de ferrocarril. Lo grave es que el acusado habia sufrido dos años encarcelado en concepto de prisión provisional. Es más: incluso si el tribunal hubiera decidido acceder al escrito de la acusación del Ministerio público, la medida cautelar habría sido notablemente exagerada. No sólo por la escasa entidad del hecho denunciado, sino también porque el fiscal apenas solicitó que se le impusiera una multa de 250 pesetas $^{149}$.

El menosprecio y la humillación de los nativos del Norte de África resulta igualmente visible en los delitos políticos. El tribunal de urgencia de Cádiz no quiso eludir la condición étnica de un "moro" que participó en la huelga anarcosindicalista de diciembre de 1933 en la Barca de la Florida, una pedanía de Jerez. Federico Balmastar Benayan (a) El Moro, natural de Melilla, fue uno de los pocos condenados como autor, sin circunstancias atenuantes, del delito contra la forma de gobierno: seis años y un dia de prisión mayor, accesorias y costas. Los obreros habían formado un piquete de huelga y coaccionado a

146 AHTMTS, fondo de Personal indigena, leg. 49, $\mathrm{n}^{\circ} .14$, causa $\mathrm{n}^{\circ} .2441 / 1931, \mathrm{pp} .98 \mathrm{v}^{\circ}, 107-$ $108,111 \mathrm{v}^{\mathrm{o}}-113 \mathrm{v}^{\mathrm{o}}$, etc.

147 Por ejemplo, véase el exp. 18052 sobre el indulto del "moro" Alí Ben Abdelkrim Buden El Anyen en la sesión del 9-X-1931 del Consejo de Estado. ACE, Libro de Actas de la Comisión Permanente, 1930-1932, p. 219.

148 Por ejemplo, la pena de dos años, cuatro meses y un día de presidio menor por el hurto de diez gallinas en Ceuta, cuyo valor fue tasado en 60 pesetas: sentencia de la Audiencia provincial de Cádiz nº 130 (30-IV-1934). AHPCad, Penal, Sección 1ª Libro de sentencias de 1934, sig. 4227.

149 Sentencia de la Audiencia provincial de Barcelona de 17-V-1932. ACTSJC, APBar, Libro de sentencias de 1932, t. 2 , sig. 155 . 
algunos trabajadores para que se sumaran, pero no llegaron a hostilizar a agentes ni símbolos de la autoridad. No sólo se anticipó el castigo a los actos preparatorios de la sublevación -esquivando el tipo de coacciones (art. $488 \mathrm{CP}$ de 1932) y el especial de coacciones sindicales (art. 3 de la ley de huelgas de 26 de abril de 1909)-, sino que se presumió la intención de proclamar el comunismo libertario ${ }^{150}$.

Dos ejemplos bastarán para visualizar la eficacia del dispositivo racista de comienzo a fin de las diligencias en delitos contra las personas. La decapitación de un soldado marroquí en Nador llevó en septiembre de 1931 a la focalización automática de todas las sospechas en la población aborigen. De acuerdo con los mecanismos de reducción de la otredad a una condición salvaje descritos por Frantz Fanon ${ }^{151}$, la existencia de delitos de sangre tan aparatosos producía el efecto de volcar toda la investigación hacia los "moros". Los autos del sumario instruido en el ámbito castrense están llenos de muestras textuales de este condicionamiento subjetivo ${ }^{152}$. Sin soltar el ejemplo, la última de las partes del sumario afirmó sin veladuras ni circunloquios la eficacia jurídica del factor racista en el proceso militar. El auditor resolvió sobreseer el sumario porque, pese a no haber dudas acerca de la infracción criminal, las investigaciones no habian permitido concretar los posibles responsables de entre la masa indigena. Después del arresto de varios sospechosos sin mandamiento judicial y de tomar declaración a numerosos marroquies, el auditor creyó insoslayable la falta de "elementos de juicio". Dispuso la negativa a procesar a ningún sujeto con el siguiente considerando: "no existiendo cargos concretos contra determinada persona, y sin pruebas físicas o morales, en que fundamentar un procesamiento, no puede éste acordarse a prisión"153. Siempre cabrian las pruebas "morales", esto es, las convicciones.

Cuando un proceso de este cariz concluía con un sobreseimiento podía haber fracasado en su intento de imponer una condena -si es que alguna vez fue ése su objetivo central-, pero siempre cumplia satisfactoriamente una doble función. La instrucción de una causa detonaba en todo caso la lógica del castigo sin condena: con autos de procesamiento o no, justificaba la entrada en una dinámica de compulsiones personales: registros domiciliarios, cacheos corporales y detenciones más o menos prolongadas en el tiempo. A esa acción disciplinaria de índole para-penal ejercida sobre la población colonizada, los resortes de la justicia ofrecian una cobertura cultural e institucional, respaldando e impulsando la ideología racista por medio de un sistema de sospechas y acusaciones fraudulentas que tendian a magnificar la criminalidad y el salvajismo de los indigenas. Su criminalización extrema conllevaba una

150 Sentencia de la Audiencia provincial de Cádiz, en funciones de tribunal de urgencia, con fecha 3-I-1934. AHPCad, Penal, Sección 1 ${ }^{\mathrm{a}}$, Libro de sentencias de 1934, sig. 4227.

151 Frantz Fanon, Los condenados de la tierra, Txalaparta, Tafalla, 20177, pp. 29-33 para la “depravación constitucional” y pp. 232-243 para la criminalidad del colonizado.

152 A efectos de ilustración, puede citarse la clasificación de soldados marroquies según su poblado, "indigena" o "europeo", o la detención de sospechosos sin garantías de procesamiento. AHTMTS, fondo de Personal indigena, leg. 49, $\mathrm{n}^{\circ} .14$, causa $\mathrm{n}^{\circ} .2441 / 1931, \mathrm{pp} .60-64 \mathrm{v}^{\circ}, 115 \mathrm{y}$ $127-134 \mathrm{v}^{\mathrm{o}}$.

153 Decreto del auditor dado en Tetuán, 26-IV-1932. Cita en los considerandos $1^{\circ}$ y $2^{\circ}$. Ibíd., pp. $166-166 \mathrm{v}^{\circ}$. 
animalización de los colonizados, la cual operaba, en último lugar, como causa de justificación de la tutela colonial ${ }^{154}$. El sobreseimiento daría cuenta de una dimensión mínimamente garantista de no ser porque buena parte de estos procesos se activaban por motivos racistas.

La segunda plasmación interpretativa, minoritaria, consistía en un espíritu de tutela paternalista y el consecuente afán de corrección mediante el castigo. En un caso de lesiones a una mujer se aplicó la atenuante por embriaguez (art. 9.6 CP de 1870), pero se acompañó la agravante por ofensa al sexo femenino (art. $10.20 \mathrm{CP}$ ) para neutralizar el beneficio, por lo que se condenó a cuatro meses y un dia de arresto mayor, accesorias por el delito de lesiones contra un cabo de Regulares por inferir heridas con navaja a una "indigena" con la que había tenido relaciones con anterioridad ${ }^{155}$. Fiscales, instructores y finalmente tribunales sentenciadores solían buscar el castigo más alto, entendiendo que su función era la correspondiente al correctivo impuesto por el superior humano al inferior. En el presente caso, se rehuía la aplicación de la circunstancia atenuante por embriaguez, lo que se justificaba en que en el procesado ésta era habitual y por tanto no podía apreciarse como modificativa de la responsabilidad penal (art. 9.6 CP) ${ }^{156}$.

Si éstos eran los efectos sobre la población indígena, el racismo -del que el militarismo se nutria- también condicionaba la vigencia de la Constitución en el territorio peninsular. El señorío militar tenía repercusiones notables en el plano constitucional, en detrimento de derechos para vanagloria de poderes, militares por supuesto. La situación excepcional del territorio colonizado en el Norte de África confería al colonialismo una especie de efecto bumerán gracias a la expansión de la jurisdicción castrense.

Un caso ocurrido en el último cuatrimestre de 1931 nos ayudará a visualizarlas. El 20 de septiembre apareció en el conocido periódico andaluz Política un artículo titulado "Monárquicos en África". El auditor de Guerra de las Fuerzas militares de África se sintió ofendido por algunas expresiones allí vertidas por el autor, José Padilla Orrán. Así pues, la máxima autoridad militar en el Norte de África se puso en contacto rápidamente con la de Andalucía, por incidir en el área territorial de competencia de esta última lo publicado por el diario de Córdoba. El auditor de la $2^{\mathrm{a}}$ División orgánica, Francisco Bohórquez -una pieza esencial en el golpe de 1936-, ordenó abrir diligencias y al poco causa militar ${ }^{157}$.

El artículo comenzaba con la siguiente afirmación lapidaria: "Es necesario hacer resaltar que en el Marruecos español continúan los mismos manejos monárquicos que si el rey no hubiera salido de España". La denuncia no carecía

154 Davis ha desenmarañado este proceso en relación al "mito del violador negro" en los Estados Unidos, el cual no sólo alimentaba el sistema de dominación racista sino también el sexista. Angela Davis, Mujeres, raza y clase, Akal, Madrid, 2016², traducción de Ana Varela Mateos, especialmente pp. 174-179.

155 Testimonio de la sentencia del consejo de guerra dictada en Ceuta el 25-IV-1932. AHTMTS, fondo de Personal indigena, leg. 50, $\mathrm{n}^{\mathrm{o}}$ 10, pieza de embargo instruida para asegurar las responsabilidades civiles dimanantes de la causa $n^{\circ} .584 / 1932$, p. 1.

$156 \mathrm{El}$ auditor tendia a confirmar esta tendencia interpretativa. AHTMTS, fondo de Personal indigena, leg. 49, $\mathrm{n}^{\circ} .17$, causa $\mathrm{n}^{\circ} .2749 / 1931$, pp. $68 \mathrm{v}^{\circ}, 84-84 \mathrm{v}^{\circ}$ y $88-88 \mathrm{v}^{\circ}$.

157 AHTMTS, fondo República, leg. 26, nº. 396, causa n . 40/1931, pp. 1-3. 
de fundamento ni predicaba en el desierto; forma parte de las reivindicaciones que abundaron en los primeros compases de la República en la línea de depurar la administración de elementos monárquicos. El texto arremetía contra algunas "ruindades" de renombrados africanistas como Yagüe, jefe del grupo de Regulares de Alcazarquivir y "tiranuelo" de la plaza, al que acusaba de perseguir las opiniones politicas que le desagradaban, y aseguraba que todos los jueces y oficiales eran monárquicos. "A alguno de éstos le dio un desmayo cuando le quitaron el retrato del Borbón de su despacho", remachaba no sin animar al ministro de Guerra a "sanear" el asunto"158.

El instructor militar que se encargó de calificar la punibilidad del caso, el capitán Juan Anguita Vega de la plaza de Córdoba -conocido monárquico159_, subrayó otras expresiones que se le antojaron abusivas:

Así de esta manera es como los hombres emboscados en el protectorado prestigiando la República, haciendo de esta población de Alcázar un virreynato [sic] en que no se puede dar un paso sin el 'plácet' de estos militares, deshonra del Cuerpo benemérito a que pertenecen. 160

El asunto siguió adelante. Al procesado sólo le quedó una opción para eludir el sometimiento a consejo de guerra bajo la acusación de haber cometido el delito de injuriar y ofender por escrito a personas del ejército (art. 258 CJM): huir. Hay que recordar que según el auto de competencia del Tribunal Supremo de 9 de diciembre de 1931 (en línea con otro de 30 de julio de 1903) el delito de injurias al instituto armado que preveía y sancionaba el art. 258 CJM se refería a las dirigidas a un cuerpo determinado, no a las proferidas contra los individuos concretos a él pertenecientes. Con arreglo a este precedente, procedía encarrilar las expresiones escritas dentro del art. 270 del CP de $1870161 \mathrm{y}$, muy razonablemente, por el fuero común. Pero los militares afincados en África, amparados por aquella situación jurídica de guerra permanente, no estaban dispuestos a dejar escapar a quienes criticasen su dominio. La excepcionalidad colonial facilitaba la militarización procedimental y sustantiva. Son pocos y muy calificados los juicios celebrados ante el tribunal ordinario por injurias a jefe del ejército. Debia guardar relación evidente con negocios particulares o relaciones laborales para que el caso no pasara al fuero castrense, y nada garantizaba que no se solapara entonces con el delito de injurias privadas ${ }^{162}$.

158 Ibid., p. 4.

159 Como dato anecdótico: compuso la letra de la marcha monárquica de los artilleros, allá por 1914.

160 Resumen del instructor militar elevado al auditor el 28-I-1932. Ibíd., pp. $14-14 \mathrm{v}^{\mathrm{o}}$.

161 "Se impondrá también la pena de arresto mayor, a los que injuriaren, insultaren o amenazaren de hecho o de palabra, a los funcionarios públicos o a los agentes de la autoridad en su presencia o en escrito que se les dirigiere".

162 Sentencia de la Audiencia provincial de Cádiz nº 261 (24-X-1934). El procesado había publicado en el semanario Renovación (Ceuta, 17-IX-1934) acusando a un comandante de haberle estafado. Se le condenó a tres años, seis meses y veintiún días de destierro a una distancia no menor de veinticinco kilómetros de la ciudad de Ceuta. AHPCad, Penal, Sección $1^{\mathrm{a}}$, Libro de sentencias de 1934, sig. 4228. 
Después del auto de procesamiento en febrero de 1932 y algunas diligencias, fue preciso declarar en rebeldía a José Padilla, ya en julio ${ }^{163}$. Aunque el procesamiento correspondiera jurídicamente al instructor, cosa que haría el 23 de febrero, el día 10 había recibido orden del auditor de proceder a tal diligencia ${ }^{164}$. Las altas instancias tomaron cartas en la dirección del proceso. Nunca más se supo de la suerte procesal del autor del artículo. Quizá, la mejor señal de que el atrevido articulista había escapado de las manos de unos militares hambrientos de venganza.

Del caso objeto de análisis, ventilado entre finales de 1931 y mediados de 1932 -en plena efervescencia republicana por tanto, con la promulgación de la Constitución de por medio-, se desprende que el mantenimiento de un estado de guerra perenne en la zona española de Marruecos propiciaba la abrogación práctica de la distribución competencial de jurisdicciones operada por el decreto de 11 de mayo de 1931 e, incluso, el art. 95 de la Constitución. Los militares afincados en África, amparados por aquella situación jurídica de guerra permanente, abrieron este resquicio para blindar sus actuaciones. En otras palabras, la excepcionalidad colonial facilitaba la militarización procedimental y sustantiva. De acuerdo con un patrón de poder colonial al estilo tradicional, la reproducción solapada del poder colonial en las fuerzas armadas perjudicó la eficacia del orden constitucionalmente prescrito ${ }^{165}$. Esto desde el punto de vista de la legalidad constitucional en su conjunto.

Bajo el ángulo sociológico, y de gran importancia para el sistema constitucional, puede decirse que la fuerza politica del africanismo heredado del antiguo régimen se vio incrementada por la persistencia del blindaje jurisdiccional a su acción militar y civil, administrativa y política en sentido lato, en el Norte de África. Dicha área de impunidad e inmunidad gozó de un respaldo considerable que otorgó cierto halo de inviolabilidad ante eventuales críticas vertidas en ejercicio de las libertades de expresión e imprenta por los ciudadanos, pues la súper-protección no se ceñia al territorio de la jurisdicción militar africana, sino que contaba con la íntima colaboración de las auditorías de la Península para garantizar su máxima eficacia. El privilegio conferido a las fuerzas armadas tuvo en África una expresión suprema a través de este sistema material de censura, propio de los sistemas coloniales ${ }^{166}$.

Las consecuencias prácticas de este espacio de fortificación y fortalecimiento de las fuerzas armadas contrarias al régimen constitucional serían letales para la República, no sólo para los pueblos colonizados. La súperciudadanía de los africanistas, esto es, el blindaje de su autoridad por vía de impunidad e inviolabilidad, se erguía sobre la minusvaloración de la población

163 AHTMTS, fondo República, leg. 26, nº. 396, causa $n^{\circ} .40 / 1931$, pp. 31-31 vo .

164 Ibíd., pp. 14 vo-15 para el mandamiento del auditor al instructor militar (10-II-1932) y p. 16 para el auto de procesamiento (23-II-1932).

165 Aquí el fenómeno respondía a la secular experiencia de penetración del patrón de "poder colonial multiforme y ubicuo" en el detrimento del orden "constitucionalmente programado". Así lo ha presentado Bartolomé Clavero, El orden de los poderes, op. cit., pp. 231-232.

166 Puede verse una crítica a la imposición de sistemas de censura para impedir que la prensa causara molestias a la opinión autóctona en el Túnez dominado por Francia en Ho Chi Min, "El martirio de Amdouni y Ben-Belkhir" (1922), op. cit., pp. 69-70. 
indígena y la erosión de los derechos constitucionales. La continuidad de un sistema de "administración arbitraria"167, ajena a la más primaria de la fiscalización del poder por la opinión pública y opuesta incluso a la existencia de críticas de índole periodístico, dio alas al proyecto reaccionario que aniquiló el régimen constitucional en 1936. La latencia de colonialismo auspició la africanización de la Constitución por obra de un africanismo activo y resistente a los cambios constitucionales. Las perversidades del colonialismo liquidaron las libertades y derechos de los pueblos colonizados y del pueblo soberano de España, colonizado al fin en 1936.

\section{NEGROS}

El estudio del estatus procesal del afrodescendiente -de las comunidades bubis, fang, ndowes...- está atravesado por un conglomerado de poderes públicos y privados que trasciende -sin restarle importancia- el plano judicial. Tal vez sea la posición jurídico-subjetiva del llamado "negro" la más dependiente de la voluntad de la autoridad colonial. En este epígrafe examinaré las novedades jurídico-positivas producidas al calor del cambio de régimen (1) y luego las pondré en relación con la planta judicial y la distribución efectiva de competencias entre instancias jurisdiccionales (2). Para terminar de visualizar la cristalización práctica de los cambios republicanos $\mathrm{y}$, por ende, su situación de tensión o acomodamiento respecto al pasado monárquico, será precisa la inmersión en algunos documentos judiciales y gubernativos que han quedado de ciertas dinámicas del ejercicio de la autoridad española en África occidental. Éstas interesan por su eficacia diferenciada, tanto por lo que respecta a la incidencia de la lógica colonial sobre la ciudadanía peninsular -la única existente en alguna medida- (3) como respecto a la población colonizada (4). El estigma de "negro", de manera parecida al de "moro", también se conoció en los tribunales de la Península, como ponen de manifiesto el sumario y la sentencia contra uno de los principales acusados por la quema de conventos en Málaga de mayo de $1931^{168}$. Me centraré, sin embargo, en lo que sucedía en las posesiones españolas en África.

\subsection{Cambio de régimen y permanencia de Estado}

En tiempos del gobierno provisional se aprobó un estatuto colonial para los "Territorios españoles del Golfo de Guinea" -se mantuvo la denominación establecida por la monarquía- por decreto presidencial firmado el 22 de julio de $1931^{169}$. Según su exposición de motivos, "el advenimiento de la República" había significado una "modificación trascendental" en el ordenamiento jurídico que

167 Ho Chi Minh, “Algunas reflexiones sobre la cuestión colonial” (1922), op. cit., pp. 51-53.

168 La sentencia de la Audiencia provincial de Málaga nº. 1 (3-II-1936) contra Benjamín Ruiz Arredondo (a) el Negro por delito de incendio ha sido recogida por José Jiménez Guerrero, La quema de conventos en Málaga (mayo de 1931), Arguval, Málaga, 2006, pp. 243-244. Puede verse también AGA, fondo de Justicia, caja 41/8449, exp. 1860.

169 Decreto disponiendo se observen las reglas que se insertan, para el mejor gobierno y administración de los territorios españoles del Golfo de Guinea, GM, nº. 204, 23 de julio de 1931, pp. 659-661. 
debía tener una "repercusión" en el "régimen colonial de los territorios" bajo soberanía española. El preámbulo mencionaba cuáles eran las nuevas "directrices" conforme a las cuales tenía que ejecutarse el articulado del decreto. La "mayor amplitud para la libertad individual en todas sus manifestaciones", la "democratización gradual de las instituciones y ejercicio de la autoridad", la "amplia descentralización que otorgue libertad al régimen colonial", etc. dejaban asomar un cambio pero, también, los límites que lo circunscribían. El modesto entusiasmo constituyente se desvanecería cuando, ya en diciembre, se dictó un decreto semejante para Marruecos.

La base $2^{a}$ del estatuto colonial de Guinea establecía las competencias de la figura del gobernador general, nombrado libremente por el consejo de ministros a propuesta de su presidente. Aunque se le fijaba como barrera a su poder de disposición sobre los funcionarios "la independencia de los judiciales", ello se limitaba a lo tocante a "la sustanciación y fallo de los asuntos". El régimen personal y gubernativo de la administración de justicia quedaba, pues, al albur de dicha autoridad colonial. Al condicionamiento de partida se sumaban otros de gran calado que, en fin, desvirtuaban el esbozo de separación alguna entre poderes.

El estatuto venía a perfilar el régimen de excepción colonial. Entre las cláusulas que incidian directamente sobre la concepción de las autoridades y los derechos, y las relaciones de jerarquización entre ambos, destacaban las siguientes. En primer lugar, había una cláusula genérica de primacía del orden público, conforme a la cual el gobernador general tenía la potestad de dictar "cuantas medidas considere necesarias para conservar la seguridad de los territorios", con el único requisito de que informara al ejecutivo acerca de ellas (base 2.3). Entre dichas medidas se encontraban las que más adelante se denominaban "Ordenanzas provisionales urgentes", sin que se les plantearan exigencia procedimental ni sustantiva alguna (base 14.1). Lo que es más: ni ésa ni ninguna resolución del gobernador era susceptible de recurso de alzada, a menos que asî lo determinara expresamente un precepto (base 14.3).

En segundo lugar, a propósito de la aplicación de las normas, la administración de justicia se subordinaba a la cláusula de especialidad típica en los ordenamientos coloniales. Regirian las "disposiciones vigentes en España" y "las especiales que se dicten para los indicados territorios" (base 6.1), las cuales tendrian naturaleza gubernativa, pues sólo el gobierno central de la República sería competente para acometer "la función adaptadora de las leyes" por vía "reglamentaria" (base 14.1). La tabla de derechos y deberes contenida en la Constitución y en las leyes complementarias estaba supeditada a esas "adaptaciones" que eventualmente acordase el ejecutivo a iniciativa del gobernador general (base 7.1). En este campo, el estatuto colonial introducía un cambio notable respecto al pasado monárquico, toda vez que declaraba la libertad de conciencia y de culto y, en consecuencia, la necesidad de que las misiones religiosas recabasen la autorización del gobierno para llevar a cabo sus actividades (bases 7.3 y 7.4). Sin embargo, establecía el mandato de que rigiera un minimo de excepcionalidad jurídica en lo concerniente al grueso de libertades públicas constitucionalmente consagradas: "Desde luego será especial la legislación de orden público, las de reunión, asociación y Prensa” (base 7.2). Se refería a los colonos, no a los colonizados. 
Todo el estatuto partía de la discriminación racista, incluso cuando al prever la creación de una "guardia colonial" integrada por "europeos e indígenas" no se añadía ningún criterio de selección o mando (base 10). La guardia colonial del Golfo de Guinea fue investida de carácter militar mediante el decreto de 30 de noviembre de 1932, en plena República. Dicho decreto no sólo fomentó la militarización de la colonia, sino que además lo hizo en torno a ejes racistas sin el menor asomo de pudor constitucional: atribuía la condición de fuerza armada a sus efectivos siempre que estuvieran mandados por "oficiales o clases europeas" o se hallara explícitamente declarado el estado de guerra ${ }^{170}$. La militarización de las fuerzas de orden público en los niveles inferiores e intermedios contrapesó aquel gran avance de la República que había sido la desmilitarización de la figura del gobernador general.

Todo derecho de los indigenas era concesivo de la autoridad y a ella subordinada. Todo derecho de los indígenas poseía una zona gris que limitaba todo enunciado jurídico. "El Gobierno -cito un ejemplo, el brindado por la base 4.5- dictará disposiciones para facilitar el acceso a todos los ramos de la Administración al personal indígena que reúna las debidas condiciones". Pero el régimen jurídico-positivo general excluía el acceso de "negros" de las colonias a determinados puestos, si es que no fuera suficiente con la exigencia de un nivel educativo universitario inasequible para aquellos; así la LOPJ (art. 109.1) cuando exigia el requisito de nacionalidad para ejercer cargos judiciales.

No había derecho intrínseco a subjetividad jurídica, por más que diferenciada, de los aborígenes. $Y$ es que los indigenas carecian de capacidad jurídica plena; su estatuto era, a lo sumo, el de los menores de edad ${ }^{171}$. Muestra de ello es la tutela ejercida por la Curaduría Colonial en Guinea, que suplía dicha falta y trataba con los patronos sobre todas las cuestiones laborales incluso una vez promulgado y consolidado el texto constitucional ${ }^{172}$. La institución aseguraba la explotación económica de la colonia mediante la negación de la personalidad de los indígenas y esquivaba la incorporación a la normalidad constitucional del territorio colonial. De hecho, el curador había desempeñado un activo papel en el tráfico de personas durante los años de la monarquía. Volvería a hacerlo en los de la dictadura ${ }^{173}$.

170 Decreto resolviendo consultas sobre los individuos de la Guardia colonial del Golfo de Guinea tienen la consideración de fuerza armada, GM, $\mathrm{n}^{\circ}$. 336, 1 de diciembre de 1932, p. 1533.

171 Raúl Sánchez Molina, "Homo infantilis: asimilación y segregación en la politica colonial española en Guinea Ecuatorial", Revista de Dialectologia y Tradiciones Populares, nº 57 (2), 2002 , pp. 105-120. Disponible en linea: https://doi.org/10.3989/rdtp.2002.v57.i2.175 (última consulta el 19/02/2020).

172 “La situación de la Guinea Española”, África y América: revista política y comercial consagrada a la defensa de los intereses españoles en Marruecos, Costa del Sahara y Golfo de Guinea, $n^{\circ} .241 / 242,1$ de octubre de 1932, p. 3262.

173 David Carrillo fue curador en dos etapas: 1926-1931 y 1940-1943. La República lo removió del cargo, pero las autoridades fascistas volverian a confiar en él. Enrique Martino Martín, "Corrupción y contrabando: funcionarios españoles y traficantes en la economía de Fernando Poo (1936-1968)", Ayer, no. 109, 2018 (1), pp. 169-195, ver pp. 177 y 179-180. 
Además, seguía en pie el Patronato de Indigenas de los territorios españoles del Golfo de Guinea, que consolidaba la división entre "indígenas no emancipados", "indigenas emancipados" y "europeos"174.

\subsection{Jurisdicción teórica y jurisdicción real}

Al llegar la República, España contaba con colonias en la costa occidental del continente africano. Río de Oro, integrado por el territorio comprendido entre Cabo Bojador y Cabo Blanco, tenía una organización administrativa de carácter "exclusivamente militar" debido a la supuesta hostilidad de los habitantes autóctonos. Para lo que nos ocupa, el gobernador militar reunía en sí todas las funciones judiciales. En el caso del Sáhara (protectorado de Cabo Juby y colonia de Río de Oro), el gobernador general carecía de atribuciones para nombrar a los jueces instructores en el orden castrense, lo que correspondía a la Auditoria militar de Canarias y, siendo bastante elocuente de por sí, excede nuestro campo de estudio ${ }^{175}$. Los territorios situados en el Golfo de Guinea se dividian, a su vez, en dos posesiones bien diferenciadas: la Guinea continental, de un lado, y las islas de Fernando Poo, Annobón, Corisco, Elobey Grande y Elobey Chico, por otro lado. La administración de justicia penal correspondía a los juzgados municipales de Santa Isabel y Bata para las faltas y al Juzgado de primera instancia e instrucción de Santa Isabel y a la Audiencia de Las Palmas para los delitos (base 6 del estatuto colonial).

Ahora bien, hay que tener en cuenta tres aspectos para entender la verdadera estructura judicial en estas colonias españolas a través de su funcionamiento real. El primero desdibuja su faz orgánica: los delegados del gobierno concentraban atribuciones jurisdiccionales propias de las atribuidas a los jueces municipales en distritos como San Carlos, La Concepción y Assoble, según fijó expresamente una real orden de 1903176. Si los delegados del gobierno seguían siendo en su mayoría los procedentes del régimen monárquico ${ }^{177}$, esto quiere decir que existía una férrea línea de continuidad en su tratamiento a la población indígena. Los delegados que amparándose en la "libertad de reclutamiento" ampararon durante años las razias y enrolamientos de braceros para el trabajo forzado fueron los encargados de impartir justicia en años de democracia constitucional ${ }^{178}$. Ha de sumarse, a la postre, la proliferación del fenómeno en la práctica en número y en intensidad. La justicia ordinaria

174 Real orden aprobando el Estatuto que se inserta del Patronato de Indígenas de los territorios españoles del Golfo de Guinea, GM, nº. 204, 22 de julio de 1928, pp. 425-431.

175 Es ilustrativo al respecto el recordatorio del Consejo de Estado en el exp. 20.279. Sesión extraordinaria de 2-II-1935. ACE, Libro de Actas de la Comisión Permanente, 1934-1935, p. 135 $\mathrm{v}^{\mathrm{o}}$.

$176 \mathrm{Me}$ ciño a las denominaciones normativas, no a las actuales ni a las más leales hacia idiomas o sentimientos locales. La real orden de 27-VII-1903 en: Agustín Miranda Junco, Leyes coloniales, Sucesores de Rivadeneyra, Madrid, 1945, pp. 246-247.

177 FPI, Archivo Julián Besteiro, caja 241, exp. 9, cartas del presidente de la Cámara Agrícola y Forestal Oficial de la Guinea Continental española, Francisco Padrón Melián, al presidente de las Cortes de la República (1-I-1932 y 19-II-1932), pp. 17-18.

178 Sobre las reclutas forzosas: FPI, Archivo Julián Besteiro, caja 241, exp. 9, Exposición que la Cámara Agrícola y Forestal Oficial de la Guinea Continental española eleva a la Presidencia del Gobierno de la República (14-X-1931), pp. 2-3 vo. 
presentaba gran "anomalía" en los territorios guineanos, como reconoció la memoria presupuestaria de 1935. Todavía entonces, algunas plazas estaban cubiertas "con personal administrativo que no podía cumplir eficazmente con su misión"179.

El presidente de la Cámara Agrícola y Forestal Oficial de la Guinea Continental española, Francisco Padrón, envió un informe al comisario de la República en Bata sugiriendo algunas reformas. Era el año 1932. Entre los ámbitos analizados se encontraban el de las responsabilidades por los abusos del pasado y el de la justicia. A propósito de las reclutas, que Padrón no dudó en definir como una "leva de esclavos", aplaudía que la República hubiera cortado de raíz con ellas, pero lamentaba que no hubiera depurado responsabilidades penales y muchas personas siguiesen en sus cargos oficiales. Si tenemos en cuenta este relato, podría decirse que el convenio sobre el trabajo forzoso que España ratificó en 1932 estaba cumpliendo sus previsiones ${ }^{180}$. Pero es algo que no casa con algunos trabajos periodísticos de los que, por lo demás, tenemos constancia debido al seguimiento policial de algunos periodistas. Es el ejemplo de Pich Aguirre, cuya correspondencia fue intervenida en marzo de ese año a causa de sus investigaciones sobre el tráfico de personas en Guinea181.

En cuanto al segundo punto, el representante de la patronal aducía que la República no había hecho "absolutamente nada" en comparación con el sistema judicial heredado del régimen anterior. A diferencia de lo que ocurría en Marruecos ${ }^{182}$, no existía ningún tribunal indigena oficialmente reconocido. Las "palabras" -como se conocía a los pleitos- eran resueltas por el guardia colonial del puesto más inmediato o por el delegado del gobierno. La incomunicación entre el área continental y el área insular tornaba inviable cualquier atisbo de justicia, pues a falta de un registro de penados y presos, los indigenas se desplazaban de Fernando Poo al continente y viceversa, obteniendo con ello "el indulto de su pena". Los indigenas que sí eran encarcelados pasaban a ser braceros gratuitos al servicio de Obras públicas o del Consejo de vecinos y, además, quedaban

179 ACD, leg. 671, $\mathrm{n}^{\circ} .1$, Memoria sobre el proyecto de presupuestos de gastos e ingresos de las posesiones españolas del Golfo de Guinea para 1935, p. 8.

180 Sobre la incorporación del convenio al ordenamiento jurídico español de la República, véase: Bartolomé Clavero, "España en la Sociedad de Naciones, 1920-1939", disponible en https://conversacionsobrehistoria.info/2020/02/09/espana-en-la-sociedad-de-naciones-19201939 / (última consulta el 19/02/2020). La "primacia" del derecho internacional en el marco de la Constitución de la República española fue reconocida desde el comienzo por la doctrina europea. Un ejemplo en Carlos A. D'Ascoli, La Constitution Espagnole de 1931, Pierre Bossuet, Paris, 1932, pp. 171-172. Es un punto capital del texto constitucional que no dudó en subrayar M. B. MirkineGuetzévitch en su prefacio a dicho trabajo.

181 AHN, MG, serie A, leg. 18/2, exp. 12, $n^{\circ}$. 10, telegrama $n^{\circ} .1309$ del gobernador civil de Santa Cruz de Tenerife al ministro de la Gobernación (30-III-1932). Enrique Martino ha sacado a colación un interesante informe fechado el 24-V-1936 que confirmaría la persistencia de este atropello durante los años republicanos. Enrique Martino Martín, "Corrupción y contrabando: funcionarios españoles y traficantes en la economía de Fernando Poo (1936-1968)”, op. cit., p. 195.

182 Además de lo que se viene exponiendo en este trabajo sobre el colonialismo español en el Norte de África, puede verse una comparación general entre aquel y el desarrollado en África occidental en Gonzalo Álvarez Chillida y Eloy Martín Corrales, "Haciendo patria en África. España en Marruecos y en el golfo de Guinea", en Javier Moreno Luzón y Xosé M. Núñez Seixas (coords.), Ser españoles: imaginarios nacionalistas en el siglo XX, RBA, Barcelona, 2013, pp. 399-432, singularmente pp. 420-421. 
endeudados por el tiempo de su estancia en prisión. Lo que para los varones significaba una justicia expoliadora, estimulaba el tráfico machista en el caso de las "mujeres depositadas"183. Los colonos españoles se lavaban las manos respecto a éstos y otros problemas con un manido tópico, el de la leyenda negra ${ }^{184}$.

Los "Tribunales de Raza" seguian siendo un proyecto pendiente en $1935^{185}$ $\mathrm{y}$, a decir verdad, no se institucionalizarian hasta la dictadura franquista. Así, los indígenas sólo tenían derecho al fuero penal ordinario cuando se comprobaba que se habian convertido al cristianismo, en virtud a la real orden de 23 de julio de 1902 (art. 9). Esto generó controversias debido a la laicidad establecida en el art. 27 de la Constitución republicana pero, mientras tanto, los jueces de instrucción siguieron investigando la conversión de los inculpados indígenas ${ }^{186}$. Uno y otro factor hacian que la justicia relativa a la población autóctona quedara mayoritariamente en manos de las autoridades gubernativas y policiales y que uno de los escasos cambios de entidad constitucional introducidos por el estatuto de 1931 -la libertad de conciencia y culto- perdiera eficacia ${ }^{187}$.

\subsection{Lógica colonial y justicia para blancos}

La documentación conservada sobre el homicidio del gobernador general de Guinea a manos del delegado del gobierno en Annobón nos arroja información interesante sobre el funcionamiento de la administración colonial ${ }^{188}$. Hacia noviembre de 1932, el sargento de la Guardia civil que ostentaba el cargo de delegado gubernativo en la citada isla mató inopinadamente a navajazos al gobernador general de Guinea, Gustavo de Sustoa Sthamer. El caso llegó al Tribunal Supremo porque se sembró la duda sobre si convenía aplicar la circunstancia eximente por trastorno mental transitorio (art. 8.1 CP). El Alto Tribunal lo rechazó de plano debido, sin duda, a dos motivos: la complicación de

183 FPI, Archivo Julián Besteiro, caja 241, exp. 9, carta al ciudadano comisario de la República en Bata (1932), pp. 8-9 para las reclutas y 10-11 para la justicia.

184 "La leyenda negra contra España", en África y América, nº. 239, 1 de agosto de 1932, pp. 3236-3237.

$185 \mathrm{ACD}$, leg. 671, $\mathrm{n}^{\circ} .1$, Memoria sobre el proyecto de presupuestos de gastos e ingresos de las posesiones españolas del Golfo de Guinea para 1935, p. 8.

186 Gabriel Martínez de Aragón y Urbiztondo, Memoria de 1932, op. cit., p. 20.

187 Sobre el catolicismo como herramienta de colonización en el siglo XX: Heather Jerónimo, "La Guinea Española: Religion as a Gendered Tool of Spanish Colonialism in Equatorial Guinea", Afro-Hispanic Review, nº 37 (2), 2018, pp. 109-125.

188 AHN, fondos contemporáneos, Tribunal Supremo, procesos especiales, reservado, exp. 10, recurso de casación $\mathrm{n}^{\circ}$. 675/1934. El expediente no está numerado, por lo que citaré los documentos para su fácil localización. Después de seguir el rastro al citado guardia civil, me ha sido posible comprobar que fue reprimido por las autoridades fascistas a partir de 1939. Al igual que muchos guardias civiles que integraron comités del Frente Popular, Restituto Castilla fue condenado a la pena de muerte. Quizá el antecedente judicial del que ahora nos ocupamos, fácilmente conocido pues llegó al Tribunal Supremo, influyó en el hecho de que su ejecución fuera casi inmediata a la imposición de la pena. Apenas transcurrieron cinco dias, algo inusual: solía pasar al menos un par de meses. AGHD, fondo Madrid, caja 5730, leg. 5081 y caja 6521, leg. 5837. El caso ha sido estudiado por Gustau Nerín Abad, "Socialismo utópico y tirania: la isla de Annobón bajo el cabo Restituto García (1931-1932)", Afro-Hispanic Review, no. 28 (2), 2009, pp. 311-330. 
los requisitos para que dicha circunstancia pudiera apreciarse, sobre todo en casos de conflictos sociales agudos y enfrentamientos con las autoridades -el debate sobre la exigibilidad o no de responsabilidad penal a las multitudes-, y, además, la necesidad de no sentar un precedente de impunidad en los atentados contra la vida de un alto cargo de la autoridad. Si se recuerda el contexto colonial del crimen, ambas variables explicativas cobran mayor fuerza.

Como las partes procesales eran españolas, correspondió conocer a la administración de justicia; como el crimen fue común, a la jurisdicción penal ordinaria. La documentación aporta valiosas referencias sobre las relaciones reales de poder existentes en la colonia. Me ocuparé de las que hacen alusión a las funciones jurisdiccionales reales, contasen o no con cobertura jurídicopositiva.

La sentencia no tuvo reparos en reconocer que el delegado del gobierno actuó "desde su llegada [en marzo de 1930] con una autonomía que envidiarían los primeros virreyes del Nuevo-mundo" 189 . El voto reservado que algunos magistrados firmaron subrayaba que el delegado del gobierno en Annobón gozaba de "una plena autonomía de hecho que le faculta[ba] para regir la vida toda de la Isla (organización religiosa, sanitaria, traslado del pueblo y creación de uno nuevo perfectamente, en lo posible, urbanizado)". Entre los motivos que probaban su trastorno psiquiátrico, los magistrados disidentes remarcaban "la influencia morbosa indudable del aislamiento social (sólo vivian 5 blancos en la Isla)"190. La resolución había reconocido la relevancia del escaso número de "europeos" para calibrar la salud mental del acusado, pero los magistrados disidentes veían en ello una circunstancia eximente ${ }^{191}$.

De este tipo de documentos se infieren varias ideas concluyentes sobre cuál era con la monarquía y cuál siguió siendo con la República el sistema de justicia en la Guinea colonial. En primer término, las autoridades coloniales gozaban de plenos poderes en la totalidad de las materias. Una serie de prejuicios racistas acerca de las supuestas patologías sufridas por los europeos en un entorno de "negros" aseguraba una práctica irresponsabilidad de aquéllos en su trato hacia los segundos. La irresponsabilidad sólo declinaba ante los derechos y, puesto que éstos sólo se les atribuían a los ciudadanos españoles, la ausencia de responsabilidad por los daños y abusos causados a la población africana era absoluta. La precariedad orgánica y personal de los órganos de justicia para la población colonialista -según hemos visto en declaraciones oficiales- hacía ver que lo sustantivo no eran los derechos de los españoles sino los poderes o, en última instancia, el principio de autoridad.

El de África occidental era un espacio sustraído a la apariencia de justicia. El orden colonial permaneció impasible a la llegada del orden constitucional en 1931. La indeterminación de los poderes atribuidos a las autoridades coloniales facilitaba una absorción de poderes y relegaba los constituidos -como el judicial, personificado aquí por la Audiencia de Las Palmas- a un perfil meramente

189 Sentencia de la Audiencia provincial de Las Palmas n ${ }^{\circ} .131$ (11-VII-1934). Considerando $3^{\circ}$. Se encuentra en el AHN, como se detalla en la nota anterior.

190 Voto reservado de los magistrados Gonzalo F. de Castro y Francisco González Palomino, 12VII-1934. Considerando $5^{\circ}$.

191 Resultando $1^{\circ}$ de la sentencia. 
consultivo, casi espectador y, sobre todo, condescendiente. Se confirmaría el "aviso metodológico" planteado por Clavero de cara al estudio del derecho colonial: su entera puesta a disposición de la autoridad colonial ${ }^{192}$.

En segundo lugar, hay que hacer alguna puntualización respecto al derecho aplicable. A nivel sustantivo, el derecho podía ser general con especialidades -el derecho español vigente adaptado a las colonias- y netamente excepcional, subordinados ambos a los imperativos del orden público y la razón de Estado colonial. Esto quedó de manifiesto desde que se inició la revisión de responsabilidades por las politicas de la dictadura de Miguel Primo de Rivera. Por ejemplo, el contrato con la Compañía de África Occidental para la prestación del servicio de comunicaciones marítimas del Golfo de Guinea fue objeto de fiscalización. El Consejo de Estado observó que la sociedad mercantil había cometido distintas infracciones toleradas por la autoridad durante tiempos de la dictadura, pero propuso que no se rescindiera el convenio, primando los intereses de colonización sobre todos los demás ${ }^{193}$. Por otro lado, aunque las normas procesales serian las comunes y el juicio oral sería público en la sede de la Audiencia de Las Palmas, en las islas Canarias, en ningún momento sería competente el tribunal del jurado para el conocimiento de ningún delito ${ }^{194}$. En otro plano fuertemente alterado por las reformas republicanas, los jueces municipales tampoco eran nombrados por elección popular, según las normas implantadas en la Península. La población negra estaba excluida del derecho de sufragio, lo que impedía el menor de trasvase de poder a favor de aquella ${ }^{195}$.

El condicionamiento del marco constitucional al interés colonial era rotundo ya en el primer bienio republicano; antes, por consiguiente, de que la militarización generalizada de la administración llevada a cabo en el segundo bienio ahondase en la tradicional excepcionalidad colonial. En Guinea habia un ínfimo número de españoles, todos dedicados de un modo $u$ otro a la administración colonial. No había obreros, y mucho menos sindicatos. Dificilmente podian originarse problemas como los que hemos indicado en las plazas de soberanía del Norte de África. Sin embargo, se produjo una reversión semejante de lógicas coloniales anticonstitucionales en detrimento de ciudadanos de la Península, ya que Guinea se utilizó como punto de extrañamiento. Si el ejecutivo trasladaba alli a los detenidos gubernativos por razones sindicales y politicas era, como exclamó Tierra y Libertad, porque "las tropicales tierras de la

192 "Los textos normativos -cito- nos ofrecen una idea ligera, muy ligera, de la experiencia efectiva que sería sin duda peor, bastante peor, para los derechos, esto es para las personas". Clavero ha analizado este asunto, tomando como hitos el estatuto orgánico de 1868 para las islas del Golfo de Guinea y el reglamento de trabajo indígena de 1906. Bartolomé Clavero, Constitucionalismo colonial: oeconomía de Europa, Constitución de Cádiz y más acá, Universidad Autónoma de Madrid, Madrid, 2016, pp. 337-338, 342-343 y 345.

193 Demófilo de Buen votó en contra. Sesión del 18-XII-1931. ACE, Libro de Actas de la Comisión Permanente, 1930-1932, p. 288.

194 Rafael de Pina, Manual de Derecho procesal penal, op. cit., p. 368.

195 Orden de la Dirección general de Marruecos y Colonias nombrando juez municipal letrado de la Guinea continental a D. José Monche García, actualmente registrador de la propiedad interino en Ibiza, GM, $\mathrm{n}^{\circ}$. 220, 7 de agosto de 1932, p. 1022. El decreto convocando el concurso para proveer la plaza se encuentra en la GM, $\mathrm{n}^{\circ}$. 170, 18 de junio de 1932, p. 2013. En el segundo bienio se cambió el titular: orden nombrando juez municipal letrado da D. Julián Cortés Ossorio, GM, $\mathrm{n}^{\circ} .37,6$ de febrero de 1935, p. 1101. 
Guinea" estaban "al margen de toda legalidad constitucional y todo sentimentalismo". El texto costó un proceso penal a su director bajo dos acusaciones, la de delito de injurias a la autoridad y la de provocación a la rebelión ${ }^{196}$.

Tomaré como caso de estudio el de la huelga general anarcosindicalista efectuada en enero de 1932 en el Alto Llobregat, que dio lugar a la deportación de numerosos huelguistas ${ }^{197}$. La patronal colonialista se opuso desde el comienzo a que los detenidos por la movilización fueran confinados en Bata, como había decidido el gobierno de Azaña en aplicación de la LDR. La Cámara Agrícola forestal de Guinea continental telegrafió al ministro de Gobernación proponiendo que los revolucionarios detenidos fueran recluidos en otro lugar. Señalaba la costa del Sáhara español como destino más adecuado, dada la escasez de población indigena allí y debido a un fin no confesado: aquella zona facilitaba un punto de fuga hacia la jurisdicción castrense. Aunque se indicó la carencia de viveres e infraestructuras adecuadas para acoger el contingente de detenidos, el principal motivo de descontento con la resolución del ejecutivo aludia a necesidades de orden público. El único hospital existente tenía apenas seis camas, las cuales eran "insuficientes para europeos enfermos" desde antes de la llegada de los presos. Pero lo relevante era la conservación del orden colonial.

Padrón, el presidente de la cámara, no tuvo reparos en realizar algunas advertencias al gobierno republicano. A los colonos les preocupaba cómo conservar la subordinación dócil de los "negros". "Necesario tengan en cuenta aseveraba- que disciplina indígena solo está obtenida por el prestigio de la raza blanca". Eso, y ninguna otra causa, hacia posible que 100.000 aborigenes estuvieran "sometidos a la dirección de 200 colonos europeos", ya que las fuerzas coloniales estaban integradas por tres compañias de indígenas que estaban mandadas por diez oficiales europeos. A los colonos les abominaba la llegada masiva de presos politicos y sociales. La "convivencia obligada de estos indeseables con población indigena" crearía conflictos de orden público que harian de aquella colonia "un segundo Marruecos" a corto plazo con "el agravante" de la "indisciplina" latente en Guinea y la mayor distancia de ésta respecto a la metrópoli, lo que crearia "reclamaciones internacionales". El desembarco de una fuente potencial de desequilibrios en la "situación colonial" obligaría al abandono de la "obra patriótica de colonización"198. Como decía otro telegrama enviado por una empresa colonizadora al ministro Casares Quiroga, la

196 El juicio al director del órgano de la Federación Anarquista Ibérica, Antonio Sarrau Español, fue celebrado ante el tribunal popular del jurado. Quizá sólo por eso pudo resultar absuelto. Véase la sentencia de la Audiencia provincial de Barcelona de 23-VI-1933. ACTSJC, APBar, Libro de sentencias de 1933 , t. 4 , sig. 161. No fue la primera ni la última vez que Sarrau fue llevado a los tribunales por el contenido del periódico.

197 Pueden consultarse los antecedentes de algunos de estos huelguistas, con registro de su estancia en los buques, en: ANC, fondo Generalitat de Catalunya, leg. 9488, declaración de Antonio Moreno Alarcón ante el agente inspector Antoni Grau (14-VII-1934). En dicha caja hay otras declaraciones análogas, como la de Juan Alcon Medina (15-VIII-1934).

198 AHN, MG, serie A, leg. 18/2, exp. 9, $n^{\circ} .1$, telegrama $n^{\circ} .694$ de la Cámara agrícola forestal de Guinea continental al ministro de Gobernación (17-II-1932). 
llegada de "elementos disolventes" a Guinea sería "altamente perjudicial" para la obra colonial por motivos de "orden moral y material" 199 .

Como consecuencia de estas presiones, el desembarco se aplazó sine die. Algunos de los detenidos fallecieron a causa de las enfermedades contraídas en aquellas deplorables condiciones, y los facultativos del barco temieron que la cifra aumentara si no se desalojaba con urgencia. En cambio, el gobernador general de Guinea se puso del lado de la patronal e hizo todo lo posible para que los deportados no pisaran tierra guineana. Estaba convencido de que se producirian alborotos que exigirian una "represión" cuya repercusión en la Península podía ser negativa. Además, declaraba carecer de locales "en debidas condiciones [de] seguridad y salubridad"200. Finalmente, los intereses coloniales prevalecieron sobre la salud y la vida de los apresados en el vapor Buenos Aires. Su desembarco no se produjo hasta el 3 de abril y en Villa Cisneros (Sáhara) ${ }^{201}$. La campaña de los colonos del Golfo de Guinea alcanzó sus objetivos si se tiene en cuenta que las nuevas remesas de deportados recalarian en el mismo punto, como sucedió con otros anarquistas ${ }^{202}$ y con los involucrados en el golpe monárquico de agosto de $1932^{203}$.

En tercer y último término, por lo que hace al momento aplicativo y lo que éste tiene de sintomático, hay que tener en cuenta que prevalecía la administrativización del fenómeno jurídico, por no decir su gubernamentalización. En lo concerniente a la aplicación judicial, había algunas prácticas relevantes que añadian un plus de complejidad al ya de por sí régimen excepcional que venimos diseccionando. Seguramente tenian una relación directa con la inercia fuertemente consuetudinaria del derecho colonial -como ha estudiado Clavero ${ }^{204}$ - o con aquella Constitución material de "España en Guinea" -como ha sostenido Petit²05-, en la que tan neurálgica función desempeñaba el

199 AHN, MG, serie A, leg. 18/2, exp. 10, $n^{\circ} .16$, telegrama $n^{\circ} .473$ de la Colonizadora de Guinea Continental (Barcelona) al ministro de Gobernación (12-II-1931). En igual sentido: telegrama $n^{\circ}$. 486 de Ferrer Vidal, presidente de la Compañía Nacional de Colonización Africana (13-II-1932). El primer telegrama también fue dirigido al presidente de las Cortes el día 17, por su calidad de presidente de las Cortes: FPI, Archivo Julián Besteiro, caja 241, exp. 20, pp. $28-29$.

200 AHN, MG, serie A, leg. 18/2, exp. 9, $n^{\circ}$. 1, telegrama $n^{\circ} .227$ del Gobernador general de Guinea al ministro de Gobernación (7-III-1932).

201 Ibíd., telegrama $\mathrm{n}^{\circ}$. 1294 del jefe de expedición del buque Buenos Aires a ministro de Gobernación (30-III-1932) y telegrama $n^{\circ}$. 103 del gobernador de Villa Cisneros al ministro de Gobernación (3-IV-1932).

202 Por ejemplo, véase la sentencia de la Audiencia provincial de Barcelona dictada el 25-I1933, resultando $1^{\circ}$. La información sobre la deportación gubernativa a Río de Oro (Sáhara) de Aquilino Ferrer Clavel "por su actuación extremista de acción" se encuentra, como si de un antecedente penal se tratara, en la relación de hechos probados. ACTSJC, APBar, Libro de sentencias de 1933, t. 1 , sig. 158.

203 “145 deportados a África”, en Gaceta Jurídica de Guerra y Marina (Madrid), agosto de 1932, pp. $137-138$.

204 Bartolomé Clavero, "Bioko, 1837-1876: constitucionalismo de Europa en África, derecho internacional consuetudinario del trabajo mediante", Quaderni fiorentini per la storia del pensiero giuridico moderno, vol. 35, $\mathrm{n}^{\circ}$. 1, 2006, pp. 429-556.

205 Carlos Petit, "Detrimentum Rei Publicae. Constitución de España en Guinea”, en José María Portillo y José María Iñurritegui Rodriguez (eds.), Constitución en España: orígenes y destinos, Centro de Estudios Politicos y Constitucionales, Madrid, 1998, pp. 425-494. 
ingente poder de adaptación ejercido por las autoridades coloniales respecto al derecho estatal. El caso es que hallamos manifestaciones concretas de este fenómeno en los años 1931-1936. Ya las hemos anotado. La academia podía justificarlo o jibarizarlo, pero no lo ocultaba. Por ejemplo, el procesalista Rafael de Pina reconoció que un entramado de delegados del gobierno desperdigados por los territorios -guardias civiles y coloniales en su mayoria-detentaban "limitadas funciones judiciales, menos importantes que las de los Jueces municipales de la Península". Ya hemos visto al estudiar el crimen de Annobón que la apreciación se queda corta, pero resulta ilustrativa del conocimiento generalizado de una realidad. Según Pina, las leyes de enjuiciamiento civil y criminal regían el proceso civil y penal, aunque con "ligeras variantes". En el fondo no eran tan ligeras, y la exposición -plagada de matices- exige una lectura atenta. Los juicios en los que los procesados eran "negros no cristianizados" se ventilaban ante el Juzgado de primera instancia e instrucción de Santa Isabel. Todos los demás, incluidas las apelaciones en lo civil, se veian en la Audiencia de Las Palmas ${ }^{206}$.

En conclusión, había un aparato infra-legal y para-judicial, no sólo una interpretación racista del derecho, que negaba y se solapaba sobre cualquier sistema jurisdiccional indigena. Esto convierte a la justicia ejercida sobre la "raza negra" -como a menudo era referida- en la más extrema de las formas de discriminación que vengo relatando. Las críticas ciudadanas lanzadas contra la administración colonial desde la seguridad de la Península, es decir, el ejercicio de las libertades de expresión e imprenta en territorio constitucional topaba a menudo con procesos penales bajo acusaciones como la de injurias a la autoridad $^{207}$. La sustracción de ese fragmento colonial del Estado a la vigencia de la Constitución implicaba restringir el ejercicio de derechos constitucionales alli donde la Constitución regía. El estatus colonial estaba blindado.

\subsection{Lógica colonial y justicia para negros}

En lo que más atañe a la población colonizada, el impacto de dicho sistema podrá ilustrarse con una referencia a las relaciones de producción. En el Golfo de Guinea imperaba una disciplina laboral que contaba con un enérgico sistema de castigo, el cual incluía la privación de libertad por infracciones cometidas en la esfera laboral y sin atisbo de tutela judicial. La "estancia en el barracón" estaba planteada durante 5-20 dias para el bracero indigena que se negase a trabajar "sin causa justificada", y de 5-30 dias para el que incurriera en "desobediencia contumaz" y para quien se ausentase o se desplazara "sin permiso de su patrono". Tan sólo el bracero que se insubordinara con agresión a las personas o a las propiedades sería puesto a disposición judicial, sin menoscabo de su

206 Luis Jiménez de Asúa, Manual de Derecho penal conforme al programa del tercer ejercicio de las oposiciones al cuerpo de aspirantes a la judicatura y de acuerdo con el programa de cátedra del autor, vol. II, Reus, Madrid, 1933, pp. 245-246. Santiago Sentís Melendo, Derecho procesal civil, criminal y organización judicial, op. cit., pp. 175-176.

207 Así la sentencia de la Audiencia provincial de Barcelona de 18-I-1934. Se juzgaba al periodista Domingo Castillo García por publicar un artículo en la revista España en África (Barcelona) en el que ponía en cuestión la moralidad y la licitud de ciertas concesiones de tierras guineanas realizadas por la Dirección general de Marruecos y Colonias. Finalmente se dictó un fallo absolutorio sin entrar en el fondo del asunto debido a que el Ministerio fiscal retiró la acusación y, como es sabido, primaba el principio acusatorio en el sistema penal español. ACTSJC, APBar, Libro de sentencias de 1934, t. 1, sig. 164. 
internamiento durante 30-60 días. El bracero que incitase a otros a abandonar la labor, ya fuera en su finca o en otra, estaría preso entre 45 y 90 días, sin necesidad de pronunciamiento judicial. Como medida disuasoria, las quejas indigenas cuya "falsedad" y carácter injustificado se comprobara también llevarian a sus promotores a pasar de 15 a 30 días bajo arresto.

Este régimen fue regulado por primera vez en un reglamento de 1906, que fue reformado en las décadas de 1910 y 1920. La República hizo algunas alteraciones en fecha tan tardía como 1935208, pero no suprimió las penas extrajudiciales, de imposición patronal, consistentes en el encierro en barracón para aquellos braceros negros que intentasen ejercitar lo que, desde otra perspectiva -la constitucional-, eran la libertad de trabajo, la libertad de circulación, el derecho de manifestación o el de huelga. Aunque durante la etapa del gobierno frentepopulista se endurecieran las sanciones contra los patronos que impusieran castigos corporales a los braceros indigenas ${ }^{209}$, el régimen sancionador que afectaba a estos últimos siguió incólume ${ }^{210}$.

Costaría imaginar una pervivencia preconstitucional más grave en la definición de derechos y poderes contradictorios con el modelo constitucional instaurado en 1931 si no fuera porque, en este punto, el ánimo constituyente apenas difería del bagaje recibido. El socialista Luis Jiménez de Asúa, en su famoso discurso preliminar al proyecto de Constitución, no hizo ninguna mención a la situación de los pueblos originarios de África en cuanto a la titularidad de los celebrados derechos fundamentales ${ }^{211}$. Antonio Jaén Morente, de la Derecha Liberal Republicana, planteó una enmienda al proyecto encaminada a la consecución de "una Constitución fecunda". Según el diputado, esto acarreaba la extensión de derechos constitucionales hacia África, pero no pensaba más que en los pueblos del Norte ${ }^{212}$. Poco antes de la aprobación del texto definitivo se produjo un interesante debate sobre otra enmienda similar. También seria rechazada, después de que Niceto Alcalá Zamora, ex jefe del gobierno, zanjara el debate con unas elocuentes palabras. "Si el pleno imperio de la Constitución se establece para indígenas y para españoles -sentenció quien sería nombrado pocos dias después presidente de la República-, el peligro en el ánimo de todos es manifiesto" 213 .

Los reglamentos laborales y los decretos del gobernador general criminalizaban conductas en el marco de un sistema de justicia privada, doméstica, colonial. Ponían en tela de juicio la teórica vigencia del $\mathrm{CP}$ en las

208 Agustín Miranda Junco, Leyes coloniales, op. cit., pp. 205-210 para el reglamento de 1906 (ver arts. 70-74), 392-397 para el decreto del gobernador general que lo reformó el 27 de julio de 1913 (de donde proceden las citas) y pp. 925-927 para el decreto del gobernador general de 12 de febrero de 1935.

${ }^{209}$ Ibíd., pp. 990-991 para la ordenanza del gobernador general de 28 de junio de 1936.

210 Sobre el trabajo forzado en la Guinea española existen valiosas referencias al período que nos incumbe en Enrique Martino Martín, "Corrupción y contrabando: funcionarios españoles y traficantes en la economía de Fernando Poo (1936-1968)", op. cit.

211 Diario de sesiones de las Cortes Constituyentes, $\mathrm{n}^{\circ}$. 28, 27 de agosto de 1931, pp. 645-646.

212 Ibíd., nº. 42, 22 de septiembre de 1931, pp. 1059-1061, y nº.70, 6 de noviembre de 1931, p. 2202 .

213 Ibid., no ${ }^{\circ}$ 83, 1 de diciembre de 1931, p. 2755. 
posesiones del Golfo de Guinea y mantenían a dichas posesiones al margen de las transformaciones constitucionales llevadas a cabo en la metrópoli. Dichas conductas podian estar penadas, además, por la ley general (coacciones, incendio, excitación a la sedición, etc.), de la que la población indigena quedaba completamente excluida. Este régimen singular significaba la negación absoluta del derecho del trabajo, del derecho penal y de los pilares esenciales del Estado de derecho constitucional. De este modo, la República actualizó la vigencia de aquel régimen reglamentario para-penal, con lo que no sólo confirió validez jurídica a unas disposiciones protectoras del trabajo compulsivo, sino además moral y más ampliamente, validez seudo-constitucional. No hay prueba más sangrante de la compatibilización entre violencia colonial y estabilización constitucional que el proyecto de institucionalización, hacia 1935, de un régimen de identificación de la población negra basado en la elaboración de unos carnés que se hacian eco de los antecedentes de conducta laboral conforme al esquema mencionado ${ }^{214}$.

El sistema de dominación colonial del África occidental reposaba sobre un lenguaje propio, que no bebía ni de las disposiciones laborales ni de las penales vigentes en la Península. Al contrario, se superponía sobre ellas conformando una realidad paralela y derogatoria. En conjunto, el régimen de excepcionalidad establecido en el estatuto orgánico de 1931 reprodujo un sistema represivo extrajudicial, manejado por las autoridades gubernativas de la colonia, los cuerpos armados de orden público y, directamente incluso, los patronos. Contaba, bien es cierto, con la connivencia de la judicatura profesional, que garantizaba impunidades a agentes de la autoridad y a patronos españoles. Como se ha visto en el ámbito laboral-esclavo, la intervención del juez de instrucción sólo se preveía -como si de una tolerancia se tratase- en caso de agresión a personas o cosas, y ello en virtud de la gravedad criminal. El requisito fue empleado como una bula a la inhibición por sistema de la magistratura. Por lo demás, la intervención judicial no obstaba a los agentes gubernativos o los patronos europeos a administrar el castigo anterior a dicha acción e inmediato a la infracción.

\section{CONCLUSIÓN}

El constitucionalismo de entreguerras se distanciaba del individualismo abstracto predicado por el canon constitucional precedente. Las constituciones de la primera postguerra mundial volvieron la vista hacia un casuismo que hacía modular los estatutos de los diferentes sujetos en atención a su posición social y sus circunstancias ${ }^{215}$. El régimen español ignoró en gran medida, sin embargo, a

214 AGA, fondo Administración española en África, caja 81/8156, G-1887, exp. 6. Urge reconocer que quien ha abierto camino en estas fuentes es José Luis Bibang Ondo Eyang, quien está realizando una tesis doctoral sobre el régimen jurídico de Guinea ecuatorial bajo la dirección de Carlos Petit y Carlota Lattini, de las universidades de Huelva y Camerino, respectivamente. Debo agradecer asimismo la ayuda del historiador Fernando Jiménez Herrera para el tratamiento de la documentación.

215 Entre otros ejemplos, así sucedía respecto a las clases trabajadoras y las minorías nacionales y religiosas. Lo subrayó en 1929 Enrique Martí Jara, El Rey y el Pueblo. El constitucionalismo de la postguerra y la propuesta de Constitución española, Athenaica, Sevilla, 2017, edición y estudio introductorio de Rubén Pérez Trujillano, pp. 180-208 y 236-245. 
los sujetos colonizados, al igual que hicieron el resto de sistemas constitucionales de su entorno y, todos ellos, en paralelo al sistema de derecho internacional. El constitucionalismo social y democrático nunca dejó de ser un constitucionalismo colonial. Como ha sostenido Bartolomé Clavero, constitucionalismo y colonialismo representaron "dos caras de una misma moneda"216. Esto queda patente en la Constitución española de 1931, cuyo art. 7 comprometía al poder constituido al acatamiento de las obligaciones impuestas en el plano interestatal. Entre ellas se encontraba el mantenimiento de ciertas politicas coloniales en África. Aunque no faltaron las mejoras y el advenimiento de la República no fue totalmente en balde -recuérdese la desmilitarización gradual de algunas zonas-, muchos colectivos se vieron directamente perjudicados bajo el nuevo régimen debido a una secuencia de silencios y omisiones a la que, además, se le añadieron unas pautas de comportamiento institucional activamente discriminatorias.

En este artículo se han rastreado algunos mecanismos de vigilancia, control y castigo manejados por instancias judiciales, policiales y militares. Dichos dispositivos han quedado retratados como un conjunto de prácticas no necesariamente codificadas y en todo momento coherentes con los itinerarios históricos de las estructuras autoritarias y preconstitucionales de la administración colonial en particular y del Estado español en general. De esta manera, reprodujeron discursos racistas de forma autónoma y continuada, enquistándolos en la joven institucionalidad republicana. La perpetuación de lógicas de dominación colonial de antiguo cuño -lógicas que el constitucionalismo republicano aspiraba, si no a erradicar, sí a limitar paulatinamente- remite a la problemática relación entre el aparato estatal heredado y el proyecto republicano; una relación que puede definirse en términos de sabotaje interno del primero respecto al segundo. Asimismo, la forma y el ambiente en que dichas lógicas se prolongaron revelan la tenacidad de la ideología racista y colonialista en el nuevo bloque de poder republicano. Aunque el racismo y el colonialismo republicano confrontaron con los de tipo tradicional -como el de los militares africanistas-, compartian cierta base común.

Ahora bien, el racismo institucional, a su paso por los tribunales, adquiria una nueva dimensión, no por sutil carente de importancia. La judicatura no sólo respaldaba discursos racistas preexistentes, sino que generaba prácticas, discursos y, en fin, relaciones de poder y dominación acordes a aquellas. Fue asi como el aparato judicial comportó una agencia de reproducción social del racismo en sus relaciones con los justiciables y, por ende, de una cultura jurídica adversa a los derechos y las politicas reformistas de la República. A través de una interpretación del derecho que absorbia categorías policiales y militares netamente racistas, tanto en crímenes comunes como políticos, la administración de justicia creó estatus procesales diversos a los que correspondian subjetividades jurídicas desiguales en la titularidad de derechos y en el disfrute de aquellos que aparentemente tenian reconocidos. De esta manera, el poder judicial ostentaba una capacidad de incidencia de gran magnitud en cuanto a la concreción del régimen constitucional en realidades particulares y a propósito de

216 Bartolomé Clavero, "Derecho bajo asedio, 1936-1939. República española y Sociedad de Naciones en el escenario europeo entre constitucionalismo y dictadura", Quaderni fiorentini per la storia del pensiero giuridico moderno, vol. 47, $\mathrm{n}^{\circ} .1,2018$, pp. 257-315, cita en p. 276. 
la determinación, con el delineamiento de su eficacia real, del contenido de los propios derechos constitucionales.

La puesta en valor de la lógica colonial y el factor racista tuvo efectos sobre los derechos de ciudadanía en su conjunto. El seísmo arrolló a la población indigena de África septentrional y occidental, mas también alcanzó a ciudadanos y trabajadores -gitanos o no- de modo indirecto. La judicatura española frustró la plena eficacia del constitucionalismo republicano aprovechando las contradicciones internas de éste y las derivadas de su entronque con un ordenamiento jurídico-estatal que funcionaba a expensas de una cultura burocrática y una ideología profesional ajenas a sus novedosos principios. El presupuesto de tal frustración no era otro que la deslealtad judicial a la Constitución de 1931 y sus imperativos.

Durante 1931-1936 el racismo judicial produjo bolsas de población, es decir, grupos humanos carentes de los más elementales derechos constitucionales con arreglo a prejuicios e ideologias diametralmente incompatibles con el constitucionalismo democrático y republicano. Esto trajo como consecuencia la formación de una a-ciudadanía u otredad ciudadana por vía jurisprudencial y a través del funcionamiento cotidiano de la administración. Los órganos destinados a garantizar derechos o a limitar la actuación de los poderes no sólo se abstuvieron de esa misión que el nuevo régimen constitucional les encomendaba, sino que actuaron avalando y promoviendo normas de conducta discriminatorias y abusivas. Al cortocircuitar el intento de subordinar los poderes a los derechos, este fenómeno de resistencia institucional a los cambios favoreció el reforzamiento de sujetos contrarios al nuevo orden constitucional. Por consiguiente, lo colonial proporcionó discursos jurídicos muy tajantes de cara a la restricción del proceso constitucionalizador, de cara a la castración de la República.

Enviado el (Submission Date): 19/02/2020

Aceptado el (Acceptance Date): 24/03/2020 